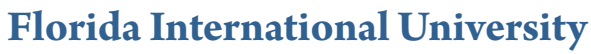

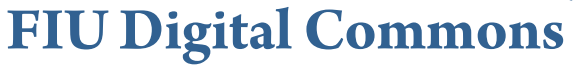

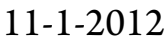

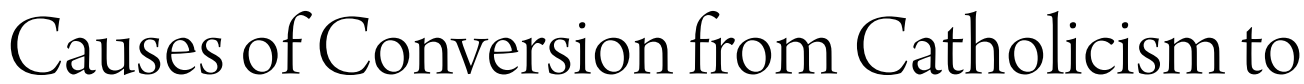

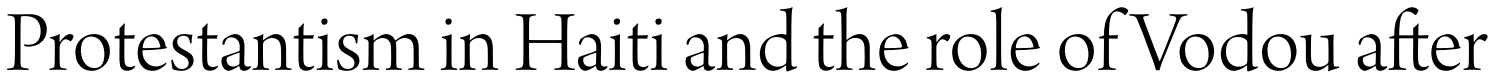

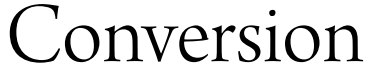

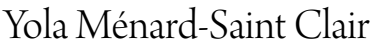

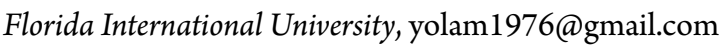

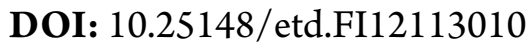

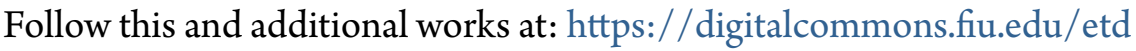

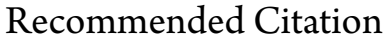

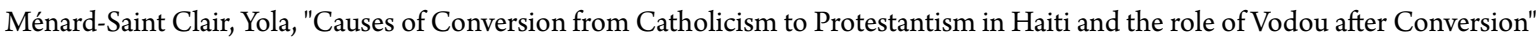

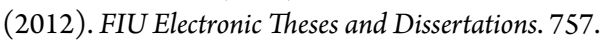

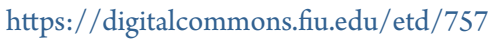


FLORIDA INTERNATIONAL UNIVERSITY

Miami, Florida

\title{
CAUSES OF CONVERSION FROM CATHOLICISM TO PROTESTANTISM IN HAITI AND THE ROLE OF VODOU AFTER CONVERSION
}

\author{
A thesis submitted in partial fulfillment of the \\ requirements for the degree of \\ MASTERS OF ARTS \\ in \\ LATIN AMERICAN AND CARIBBEAN STUDIES \\ by \\ YOLA MÉNARD SAINT- CLAIR
}

2012 
To: Dean Kenneth G. Furton

College of Arts and Sciences

This thesis, written by Yola Ménard-Saint Clair, and entitled Causes of Conversion from Catholicism to Protestantism in Haiti and the role of Vodou after Conversion, having been approved in respect to style and intellectual content, is referred to you for judgment.

We have read this thesis and recommend that it be approved.

Albert Wuaku

Astrid Arraras

Ana Maria Bidegain, Major Professor

Date of Defense: November 1, 2012

The thesis of Yola Ménard-Saint Clair is approved.

Dean Kenneth G. Furton
College of Arts and Sciences

Dean Lakshmi N. Reddi University Graduate School

Florida International University, 2012 


\section{DEDICATION}

I dedicate this thesis to my husband and children who have supported me in more ways that they can possibly imagine. They have made this process more significant to my studies and my life. I also would like to extend my appreciation to all my family members specially my mother Illienne Clotilde Sonceau Menard, father Thomas Pulcio Menard (may he rest in peace), my husband Duckens Saint-Clair, my sons Quincy Saint-Clair and Yohency Saint-Clair. A special thanks to Mirva Cadet, Aneesa Benjamin all my sisters, brothers and my sorority and line sisters of Xi Epsilon Chapter of Delta Sigma Theta Sorority Inc. 


\section{ACKNOWLEDGMENTS}

I have to thank God for given me the wisdom and the strength to have reached this far in my life. I am forever grateful to my committee members for their help and support in helping me complete this thesis. I wish to thank all committee members and Latin and American and Caribbean Studies Department at Florida International University for believing in me and providing the guidance needed to complete the thesis Dr. Ana Maria Bidegain, Dr. Albert Wuaku, Dr. Astrid Arraras, Dr. Sherri Johnson, Leo Falcon, and Dean Donnelly. I would like to thank Ougan Max Beauvoir Le Péristile de Mariani Carrefour Port-Au-Prince Haiti, Alex Saint-Surin Journalist Miami Florida, Father Leon Claret, Eglise Catholique Plaine du Nord Cap-Haitien Haiti, Father Reginald

Jean Marie, Eglise Notre Dame D’Haiti Miami Florida, and Pastor Frantz Phillipe Eglise Wesleyenne du Cap-Haitien Haiti. 


\author{
ABSTRACT OF THE THESIS \\ CAUSES OF CONVERSION FROM CATHOLICISM TO PROTESTANTISM IN HAITI AND \\ THE ROLE OF VODOU AFTER CONVERSION \\ by \\ Yola Menard-Saint Clair
}

Florida International University, 2012

Miami, Florida

\title{
Professor Ana Maria Bidegain, Major Professor
}

The purpose of this thesis was to examine the choice patterns that lead to conversion from Catholicism to Protestantism and the role of Vodou after conversion.

This study highlights disappointment with the church as the leading cause of conversion in Haiti. Other causes significant to the study were examined. In illness and healing lie the controversies of religious conversion in Haiti. The only way to cure Satanic Illness is by resorting to magic. However, conversion to Protestantism means rejection of Vodou and all of its practice. A secondary purpose is to determine the role of Vodou after conversion.

A total of 100 participants between the ages of 18 to 44 were included in this study. Seven percent (7\%) converted for economic reasons, 43\% selected disappointment with the church, 17\% community/environment encounter, $13 \%$ sickness/near death experience, $2 \%$ economic and disappointment, $7 \%$ community/environment encounter and disappointment with the church, $9 \%$ disappointment sickness and near death experience, $1 \%$ economic and sickness near death experience, $1 \%$ economic and community/environment encounter. 
Findings suggest that Vodou is deeply rooted in Haitian identity, though all Haitians may not practice Vodou; but there are characteristics in the Haitian society that suggest that Haitians are Vodouisant. For the conversion process to be successful in Haiti it has to deeply acknowledged Vodou, the religion practiced by the masses in Haiti. 


\section{TABLE OF CONTENTS}

CHAPTER

PAGE

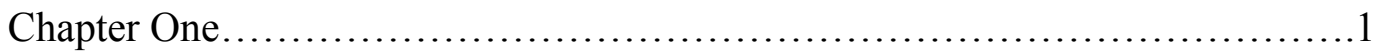

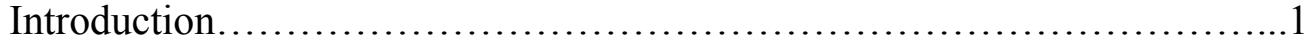

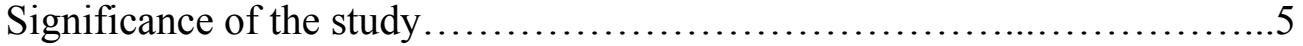

Research Design.............................................................

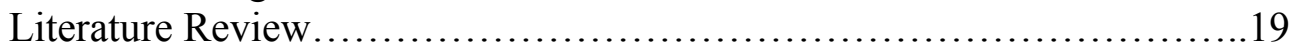

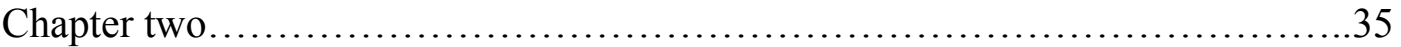

Religions during the Colonial time:

Catholicism and Vodou; Domination and Co-existence.........................................35

Chapter three.............................................................46

Modern Colonialism brings a new Religion: Protestantism..................46

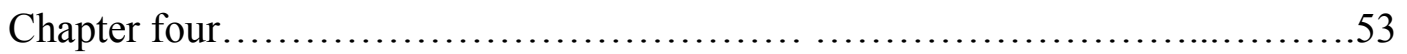

Religion of Resistance and Resilience: Vodou...........................53

Religious Manipulation: Vodou and Politics...............................60

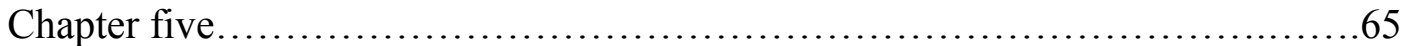

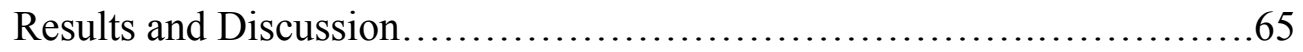

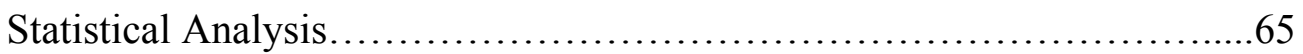

Leading Cause of Conversion........................................67

The Repercussion of Religion on Haitian Society...........................77

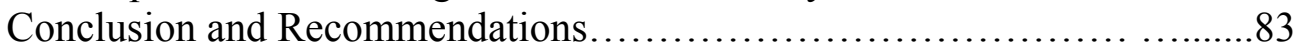

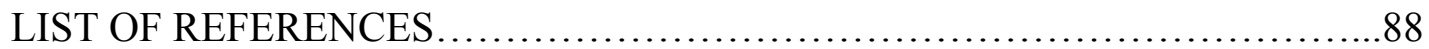

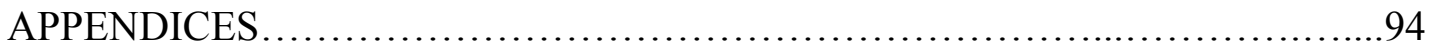




\section{LISTS OF FIGURES}

FIGURES

PAGE

1. Model: Causes of conversion from Catholicism to Protestantism in Haiti and the role of Vodou after conversion................................ 8

2. Religions in Haiti by percentage of the population and age, $1982 \ldots \ldots \ldots \ldots \ldots \ldots . . . .12$

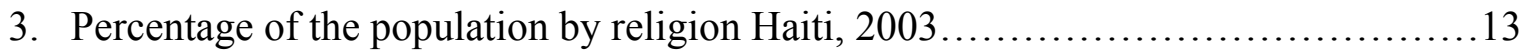

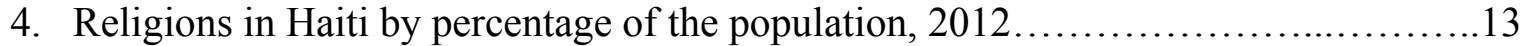

5. Percentage of the population by religion and areas of residence, $1982 \ldots \ldots \ldots \ldots . . . .46$

6. The growth of Protestantism in Haiti......................................... 48

7. Scientific Study on religion in Port-Au-Prince...................................57

8. Causes of Conversion from Catholicism to Protestantism in Haiti....................68

9. Building the inclusive community-----Haitian society ...........................78

10. Building the Discommunity--------Religion in Haiti...............................79

11. Building the inclusive community: The Discommunity, Definition, Motivations and Values of each-----Vodou in Haiti....................................81 


\section{LIST OF ABBREVIATIONS AND ACRONYMS}

\begin{tabular}{|c|c|}
\hline rcat & Rural Catholics \\
\hline ucat & Urban Catholics \\
\hline rpro & Rural Protestants \\
\hline upro & Urban Protestants \\
\hline $\mathrm{ECO}$ & Economic Condition \\
\hline $\mathrm{DCH}$ & Disappointment with the Church \\
\hline CEE & Community/Environment Encounter \\
\hline SND & Sick/Near Death Experience \\
\hline
\end{tabular}




\section{Introduction}

\section{Chapter one}

As traditional religions were being destroyed, or integrated into Catholicism, after the European conquest, Roman Catholic became the dominant and official religion. Today, there is a Protestant movement across Latin America and the carribeans where conversion is at its peak. In order to explain religious conversion in Haitian society, my study analyzes the causes of conversion from Catholicism to Protestantism in Haiti and the role of Vodou ${ }^{1}$ after conversion although Protestantism openly rejects the practice of Vodou. The thesis is an attempt to explain this tension and ambiguities in Haitian society. Conversion comes from many different perspectives; it all depends on the society in question. Flinn's definition of conversion applies more appropriately to Haitian society where conversion from Catholicism to Protestantism is very peculiar due to historical and cultural presence of Vodou.

“The word 'conversion' is derived from Latin converte which means 'to revolve, turn around' or 'head in a different direction'. This basic meaning also holds for the Biblical Hebrew word shub ('to turn, return') and the greek term strepho and epistrepho" (Flinn 1999:52).

Flinn's definition of conversion also supports Mendoza, Arthur, Bourdieu, Robinson and Clarke, Eliade and Prichard, Min, San Buenaventura theories on religion and religious conversion and that the understanding of conversion is thru social, cultural traditions or

\footnotetext{
${ }^{1}$ Vodou [Vodoun] The predominant religion, way of life in Haiti, religion practice in Haiti deeply rooted in Africa; a mixture of African tribes and cultures, Carib Indians, and Roman Catholicism. (Combine definition from Sacred Arts of Haitian Vodou and Voodoo Search for the Spirit).

Voodoo-Religion of the West Indies, esp. Haiti based on belief of African and Roman Catholicism origin, and noted for its interest in sorcery, black magic charms, and fetishes. (Webster's New World College Dictionary $4^{\text {th }}$ ed.)
} 
preexisting religions as a way of adding to or replenishing their culture which cause people to either return to their previous religions or practice more than one religion.

The study reveals that disappointment with the Catholic Church is the leading cause of conversion to Protestantism in Haiti. However, in a society where institutions that address societal needs are either poorly operated or non-existent Economic Condition, Community/Environment and Sickness/Near Death experience are also significant. While some converts adopt Protestantism rigorously, others accept only certain aspect of the new religious tradition that corresponds to the attitudes of their previous religion; because African or African based religion adopts new religion without leaving their own tradition. In addition, the study also analyzes conversion in Haitian society and explains that the total rejection of Vodou and all of its practice is illogical; because religious conversion is understood through multiple social and cultural processes (Robinson and Clarke 2003). This is also the case in Haiti where religious conversion is understood through the issues dominating the society, Catholicism and/or Vodou. Religious conversion from a wide range of culture from Africa, South America, India, and Japan is seen as means of adding a new culture to their existing cultures and the concept of total rejection of previous religion to embrace a new one is fictional (Arthur 2000). Futhermore a sample will be taken in a more developed society Miami, Florida showing the forces of Vodou across the waters and its deep seated roots in Haitian identity.

Vodou a religion transported from Africa to Haiti during the slave trade went thru a rebirth process with a mixture of Catholicism, Freemasonry and Carib Indians; Vodou became unique to the island of Haiti. The religion provides a system of beliefs, a way of 
life; it regulates social behavior, provides remedy for the sick, helps in times of hardship and provides communal support. Considering the community empowerment that Vodou sustained during the colonial era, it never received a suitable position in Haitian society.

In Haiti, three main religions find their sanctuary, Catholicism, Protestantism, and Vodou. Although Catholicism rejects Vodou, its leniency towards its practice has created the impression to outsiders that all Catholics practice the Vodou religion. Many Catholics do not support this notion. However, Catholicism has been traditionally more permissive to other religions because it has grown to negotiate and compromise with many different cultures throughout centuries. In addition, the concept of "inculturation" makes the Catholic Church more open to understanding different cultures and their way of worshipping their divinities. Furthermore, Caholicism has had a special function in the Haitian society.

Over the years, Caholicism, the dominant religion in Haiti fails to meet society's basic needs. As followers become disappointed with the Church many of them convert to Protestantism which offers certain benefits. However, Protestantism insists on the rejection of Vodou and all of its practice and the rejection of Catholicism as a prerequisite before entering the Protestant world. While many Haitians constantly and publicly deny their affiliation with the practice of Vodou, many of them turn to Vodou in time of needs. They practice Vodou in Haiti and abroad together with their alleged religion. In the history of Haiti, several policies have been implemented to outlaw the religion: The black Code, the Second Vatican Counsel, the U.S. Marines anti-suspicious campaign and now in the twenty first century a new decree which would annul article 297 of the 1987 constitution that granted Haitians the right to practice Vodou. The 
decree does not only threaten democracy in Haiti; it also disrespects the traditional religion and the memory of the revolutionary leaders which at one time thru Vodou motivated the slaves into a consensus and eventually unite themselves into the road of freedom. Despite all the efforts to "cleanse" Haiti, Vodou remains until today a religion practiced by many Haitians in Haiti and abroad.

Protestant evangelization demonizes and rejects Vodou, a religion deeply embedded in Haitian society whether by the use of a proverb, gesture, beliefs, festivities and more. Instead of instructing people on how to become productive citizens of their country, the evangelization blames Vodou for Haiti's misfortune. Haiti struggles with high rate of unemployment accompanied with weak or nonexisting institutions, geographic factors that limit the successful progress of the country and frequent natural disasters hindering the developmental process, those issues are not related to religion. Conversion in societies with social, economic and political issues is complex; before getting involved in a mission "to convert" people in Haiti, missionaries have to take into account "the dynamic emerges out of the relationship of a potential convert group with the society and culture, in which it is embedded, and its relationship with and expectations-social, cultural, spiritual and material of those who carry the new creed." (Robinson and Clarke 2003: 18). Meaning an understanding of the ideology of the Haitian people as a group, cultural values and traditions has to be understood, respected, and supported.

As stated by Cnaan, Boddie and Yancey "in society that celebrates individualism, class structure inequality, local religions congregation are at the forefront of meeting people's need and serving as our national social safety net. A function that in other 
advanced democracies is reserved for government." In order for a country to develop and for its citizens to ameliorate their living conditions people have to work. In Haiti people are led to believe that converting to Protestantism and praying will automatically regenerate a productive lifestyle. In order to meet the basic needs, at times many people attempt to change their identity or pretend to be religiously affiliated. However, understanding religious conversion in Haitian society where Vodou is a traditional religion is crucial in understanding religious conversion in Haiti.

\section{Significance of the Study}

The thesis will address causes of conversion in Haitian society and the role of Vodou after conversion. In addition, it will examine if Vodou remain relevant to diasporic Haitians. Despite all the policies implemented to outlaw Vodou, it remains until today a religion largely practiced in Haitian society. The study is significant for three reasons. First, the study examines several issues in the Catholic Church, in order to analyze the choice made by followers to convert from one religion to the other. Second, since Haitian society is largely divided by social class and people seek emotional and financial support, converting to Protestantism, which offers certain benefits, is increasing. Third, two different types of illnesses exist in Haiti: malady Bondye (natural causes) and Maladi Satan (an illness of Satan typically sent upon the victim by an enemy out of jealousy or the desire for revenge) and the only way to cure malady Satan is by resorting to magic.

The misperception of Vodou caused a generalization that has been haunting Haitians in Haiti and in the Diaspora. Vodou has been marginalized for its magical aspect portrayed as black magic which categorized it has the "devils religion." Efforts 
have been made to enlighten the world on the Vodou practiced in Haiti. Vodou took one step forward in 2003 when it was declared religion of the state by President Aristide. Today there is a new amendment in the Haitian constitution that recall article 297 that protects Vodou practitioners; the amendment may set the effort back a couple of more steps. Protestant ideology may reject Vodou and its entire practice; but the government's efforts to outlaw the religion practiced by the masses in the twenty first century is a threat to Haitian identity and the democratic process even if it is only on paper. This study will present evidence that Vodou originated from Africa, is deeply rooted in Haitian society and until today its presence dominates religion in Haiti and contradicts conversion in Haitian life.

The majority of scholars such as Hourbon: Current Evolution Between Religion and Politics in Haiti 2001, Voodoo Search for the Spirits 1995, Metraux: Le Vaudou Haitien 1995, Freedman: Myth Vodou, Source of Comfort in Haiti, 2010), McAlister: Rara!: Vodou, Power, and Performance in Haiti and its Diapora, 2002), Richman: A More Powerful Sorcerer: Conversion, Capital, and Haitian Transnational Migration have emphasized the significance of Vodou and its role in Haitian culture and identity. This study does not focus on religious studies or Vodou rituals in Haiti. The purpose of the analysis is to underline the issues in the Haitian society that are causing people to convert to Protestantism, also to comprehend the significance and the position of Vodou in Hatian society from the colonial times until today in Haiti and abroad.

My analysis of the causes of conversion from Catholicism to Protestantism in Haiti and the role of Vodou after conversion will contribute to the available literature by providing information from original interviews and field work. The thesis approaches 
religious conversion in a unique perspective relating to how Haitian Vodou is unique to Haitian society. Some converts adopt Protestantism rigorously others accept only certain aspect of the new religious tradition that corresponds to preexisting attitudes (Mendoza 2003). In times of personal crisis such as economic, employment and sickness when biomedicine fails many converts revert to Vodou. Out of the struggle to maintain cultural identity, an explanation of life's struggle and suffering, socioeconomic equality and community empowerment emerged and sustained the forces of Vodou in Haiti.

\section{Research Design}

The thesis investigates the choice patterns that lead to conversion from Catholicism to Protestantism in Haiti and if Vodou remain relevant to Protestant converts in Haiti and diasporic Haitian converts. To provide the cause or causes of conversion that triggered converts to move from one religion to another, a survey was conducted in an interview format with four causes of conversion as the unit of analysis. In addition, to examine and provide evidence of the role of Vodou after conversion, formal interviews were conducted in Haiti with lifelong Catholics, Protestant converts and lifelong Protestants, Catholic Priests, Pastors, Ougans, and servitors of spirits; the origin of Vodou and its role in Haiti since the colonial times will be presented and analyzed. A sample of Protestant converts, lifelong Protestants and Catholics was taken in Miami to briefly determine the force of Vodou across the waters and the importance of Vodou in Haitian identity. Results from the interviews and fieldwork experience highlighted the leading cause of conversion and explain the choice made by people to return to Vodou after conversion. 
The research uses two different causal models (Figure 1) with causes of conversion as the unit of analysis.

Figure: 1

CAUSES OF CONVERSION FROM CATHOLICISM TO PROTESTANTISM AND THE ROLE OF VODOU AFTER CONVERSION

(Model)

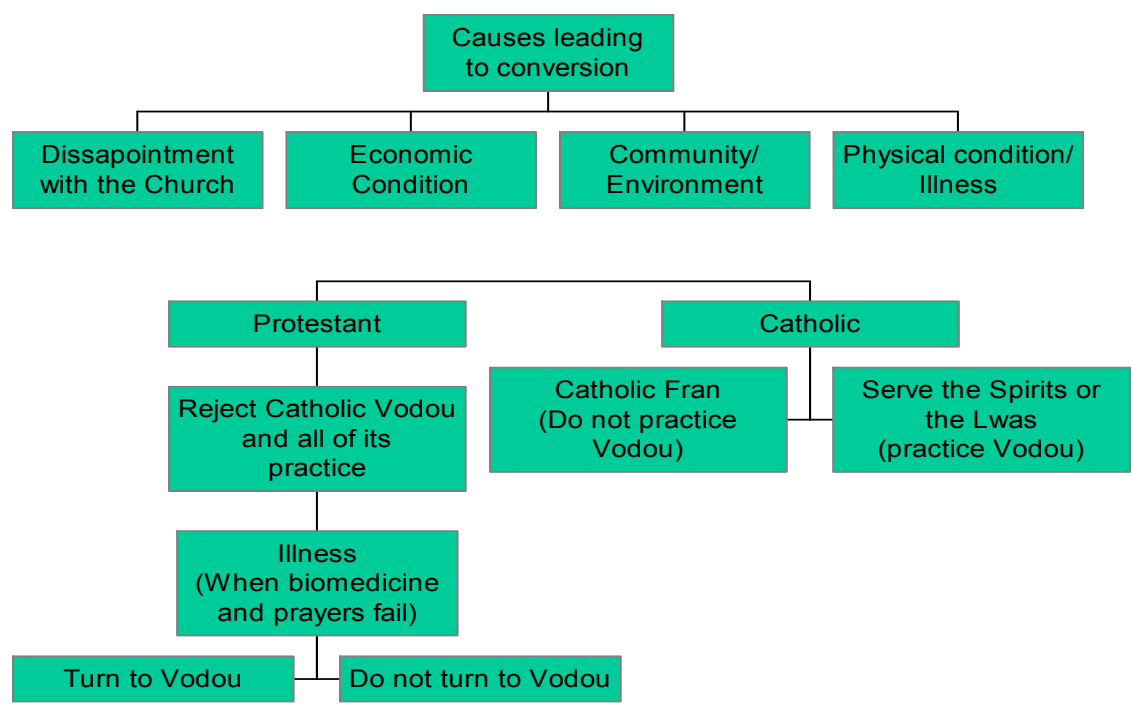

One model explains the causes of conversion: Disappointment with the Catholic Church (referring to whether or not people's basic needs are met by the church); Economic Condition of alleged convert (whether or not they are economically stable or employed); Community/Environment (people who affiliate with friends or family members who are Protestant or live in a predominantly Protestant community); Illness/Near Death experiences (refers to people who were sick or nearly passed away who look for help and received help from Protestant Churches). The other model explained the circumstances under which Protestants and Catholics will turn to Vodou. According to Smucker, in Haiti there are two types of Catholics: Those who do not serve the spirits (Catholic Frank) and those who serve the spirits or the lwas. The question remains if biomedicine 
fails will a Protestant or a Catholic Frank turn to Vodou? In order to answer the question one has to understand the definition of religious conversion in Haitian society where many will adopt faithfully the new religion and others will adopt certain aspects fused with the previous religion.

The study aims to primarily use the sociological approach to analyze religious conversion in Haiti. Researches in Haiti fail to make a clear emphasis on causes of conversion from Catholicism to Protestantism and the role of Vodou after conversion. Protestantism in Haiti contributes greatly to the Haitian society where more than half of the population struggle to meet basic needs. However, in developed countries institutions are in place to secure salaries and societal needs, clergy is not required to make special efforts to recruit new members (Cnaan, Boddie and Yancey 2003). In Haiti where institutions are either ineffective or non-existent; it is important to establish causes of conversion from Catholicism to Protestantism since half of the population practiced Vodou together with their professed religion (National Center of Diseases and World Factbook).

There are three facets to the research problem: factors in the Catholic Church leading to conversion, types of benefits perceived by potential converts, and to what extent is the change from one religion to another a personal choice. I predicted that controlling for Disappointment with the Church, Community/Environment, and Illness/Near Death experiences, people who are considered poor are more likely to convert from Catholicism to Protestantism. I also predicted that people who live in a predominantly Protestant community and whose family or friends are Protestant are more likely to convert. The study provides a list of churches and congregations active in Haiti 
by departments (Fontus 2001). This data is important when analyzing alledge converts affiliation with Protestants and the benefits perceived by followers to convert.

In Haitian society there is a saying that Agno pa jan m pèdi chemin $l^{2}$ leading to the belief that Protestant converts are more likely to return to Vodou than People who are born or grew up in a Protestant household (Enfant de la promesse), especially if the converts were believers or pratitioners of Vodou before converting. Since Vodou is an aspect of the Haitian culture total rejection of Vodou in Haitian society and full adoption of a new religion is irrational.

The research conducted was quantitative and testing of the hypotheses is made on the basis of primary archives, statistical data from Haiti census 1950, 1971, 1982 and 2003. It was not until 2003 that Vodou was acknowledged in Haiti's census. Catholicism until today remains the dominant religion and the growth of Protestantism in the urban and rural areas continues to increase from 1950 until today. Though more than half of the population practiced Vodou with their professed religion, only a small percentage of the population is reported on the census. The review and analysis of the available literature, primary sources, and field research interviews attempt to identify causes of conversion and the reason Vodou remains an important aspect in Haitian society and the circumstances under which converts or Catholics will turn to Vodou.

The study takes into account the following spelling of $\mathrm{VODOU}^{3}$ in order to accentuate the Vodou practiced in Haiti and its role in Haitian identity. The survey on causes of conversion from Catholicism to Protestantism and census data are used as

\footnotetext{
2 The lamb never loses it path.
}

${ }^{3}$ Sacred Arts of Haitian Vodou 
quantitative part of the analysis. The survey records individual's present religion; if Protestant, the cause/causes of conversion--the variables are coded into excel $1=$ disappointment with the Church (DCH), 2= Community/Environment (CEE), $3=$ Economic Condition (ECO), 4= Sickness/Near Death Experience (SND) looking for pattern in the variable leading to conversion. The analysis of Vodou in Haitian society uses survey results from individuals on Vodou-- if they agree with the demonization of Vodou, their knowledge of Vodou, the role of Vodou in religious conversion, and whether or not the individual or a family member practice Vodou. Formal interviews with Church elites and Vodou practitioners and several pieces of literature such as Lamb and Bryant Religious Conversion: Contemporary Practices and Controversies (1999), Brodwin Medicin and Morality in Haiti: The Contest for Healing Power (1996), Desmangles The Faces of the Gods: Vodou and Roman Catholicism in Haiti (1992), Evans-Pritchard and Edward Theories of Primitive Religion (1965), Rey Our Lady of Class Struggle: The Cult of the Virgin Mary in Haiti (1999), Kim Sebastian In Search of Identity (2003), Massino Religious Conversion and Identity (2004), Nerestant L'eglise d'Haiti a l'aube du troisieme Millenaire essai de Theologie Pratique et de Sociologie Religieuse (1999); Nerestant Religion et Politique en Haiti (1994), Fontus Les Eglises Protestantes en Haiti: Communication et Inculturation, Merrill Vodou and Political Reforms in Haiti (2000), Bellgarde-Smith and Michel Haitian Vodou: Spirit, Myth, and Reality (2006); Vodou in Haitian Life: Invisible Power (2006) Eugene Church Growth and Evangelism in Haiti: Needs, Problems and Methods (1997) provided information that supports Vodou as an aspect of Haitian culture and identity. Futhermore, Vodou the traditional religion that provides certain characteristics embedded in Haitian culture 
renders religious conversion in Haiti skeptical because Protestant ideology rejects Vodou and all of its practices.

Since the Colonial times, Vodou's rebellion contributes greatly to its absence in previous censuses (Figure 2).

Figure: 2

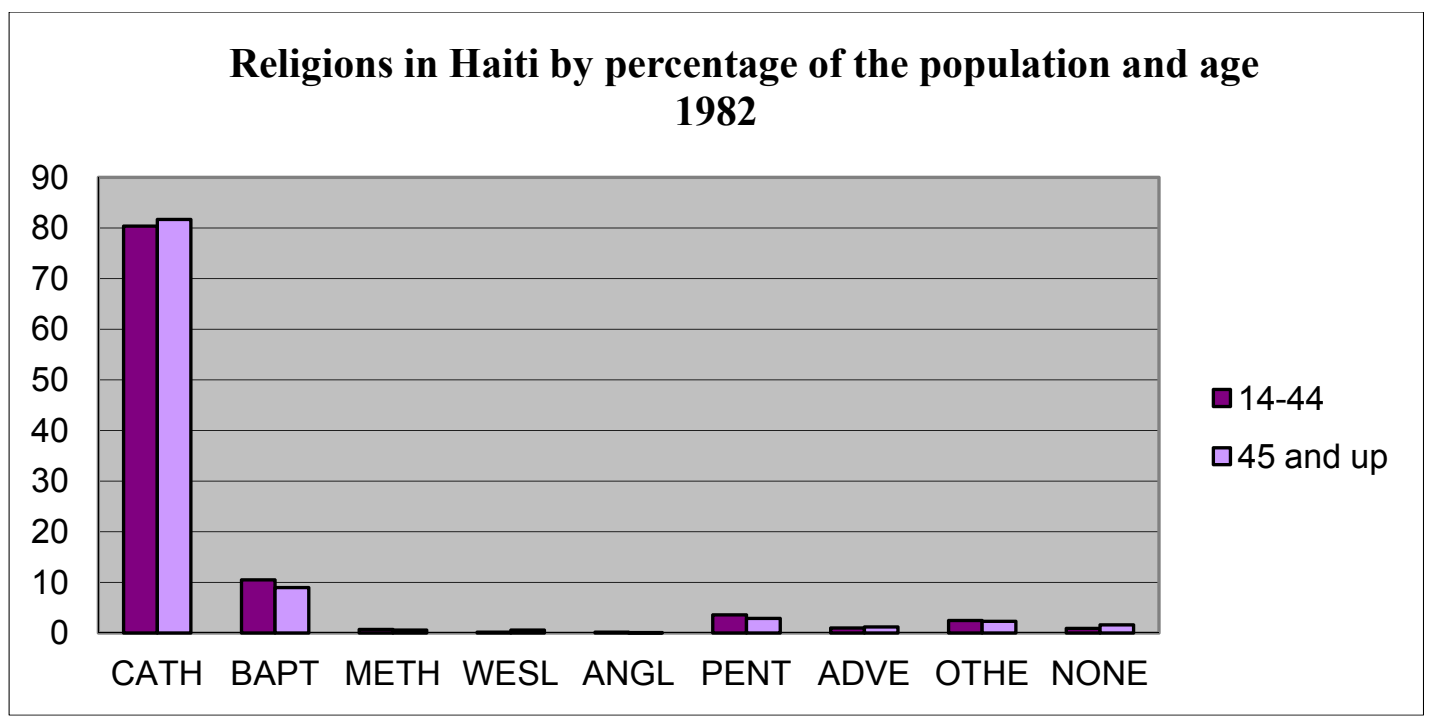

Source: IHIS, Recensement General de la Population: Census 1971, 1982

With all the efforts made locally and internationally to outlaw the practice it remains deeply in the society, as a result it has been ignored, marginalized, and demonized. After President Aristide declared Vodou religion of the State, 2003 census reveals that $2.1 \%$ of the population practiced Vodou (Figure 3). 
Figure: 3

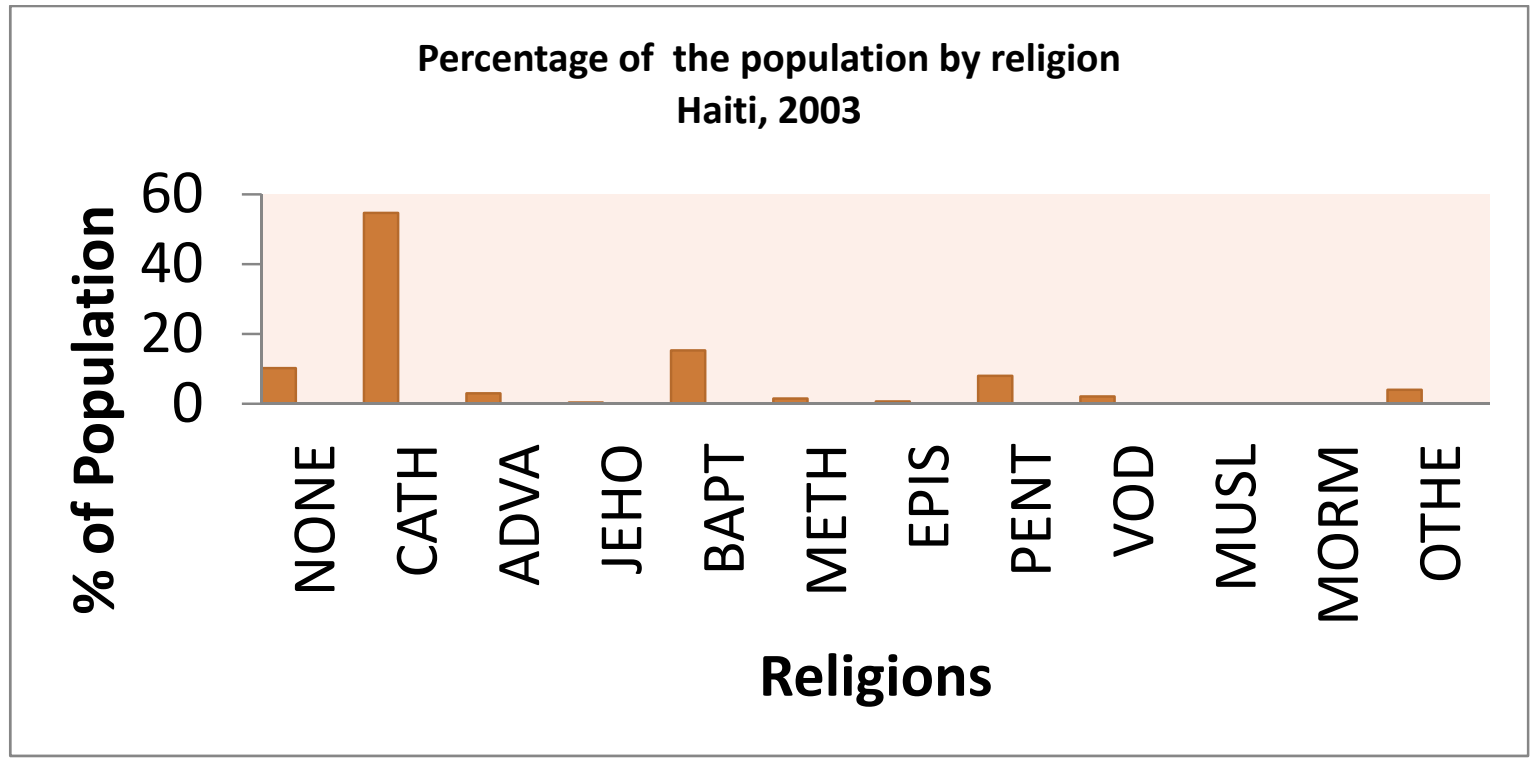

Source: IHIS, Recensement General de la Population: Census 2003

In addition the data from WorldFact Book reveals that half of the population practiced Vodou, the Southeastern National Tuberculosis Center stated that many Haitians practiced Vodou in addition to their professed (Figure 4) religion provide additional support to the forces of Vodou in Haitian society and its importance in Haiti and abroad.

Figure: 4

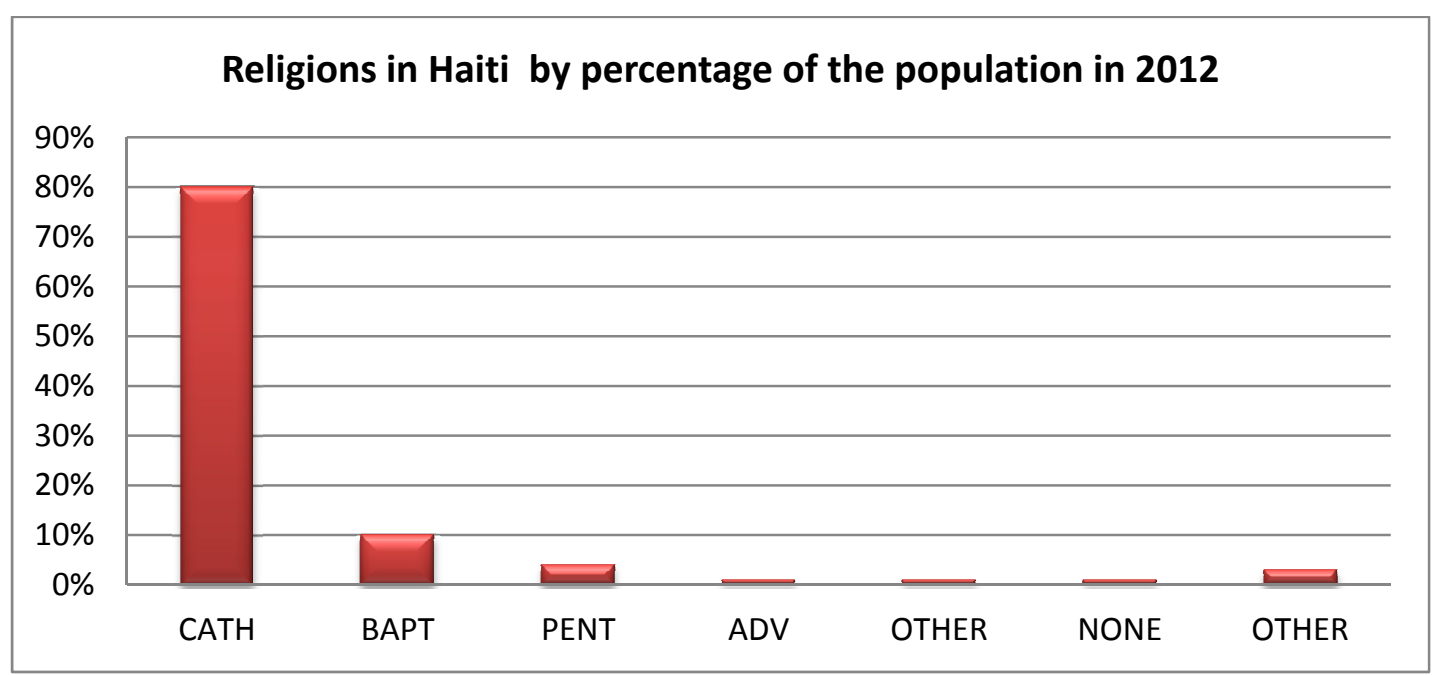


Source: WorldFact Book

Protestantism: Baptist, Pentecostal, Adventist, other

Note: Vodou rites are practiced by many Haitians in addition to their professed religion. (Catholic or Protestant) Vodou is an officially recognized religion.

Southeastern National tuberculosis center

In summary, the thesis uses the survey data on causes of conversion: Economic Condition of alleged converts, Disappointment with or lack of services provided and the issues affecting the Catholic Church, Community/Environment Protestant affiliation, and Illness/Near Death experience in Haiti will be analyzed and investigated and determine whether or not Vodou remains an important factor in the lives of Protestant converts. The target sample size for the study is approximately 100 cases. Critics may question the accuracy of the data (Figure 8) because there are several more reasons/causes why people convert from Catholicism to Protestantism in Haiti. However, the thesis uses the above four causes primarily testing for variance in the independent variable causes of conversion that can explain the change made by people to move from one religion to another. The interviews were used to determine whether or not Protestants convert return to Vodou, a religion deeply rooted in Haitian identity. In addition another sample from Miami Florida analyzes the relevance of Vodou in diasporic Haitians.

The theoretical perspective for the thesis is the theory on religion by Eliade, Edward and Evans-Prichard (1999) its ability to provide answers to deep human need for order and significance in a world of disorder, evil and suffering. Furthermore, it fills emotional and social needs. Bourdieu's religious habitus theory also supports the ambiguity of religious conversion in Haitian society; it implies that "the largely West African religious habitus of most Haitians during Vodou's formative period, even those 
several generations removed from Africa, predisposed the formulators of Vodou to assess certain foreign forms of religious capital" (Rey 1999: 208). In Haiti, religious conversion can also be explained through religious characteristics of African religious habitus; where people will convert and still retain characteristics of their previous religion. Bordieu's theory on religious habitus also expands Mendoza's claim that religion is understand through social and cultural traditions. Conversion in Haitian society and any other society with African based religion is seen in a different perspective than Protestant ideology of conversion. In fact, conversion is not a rejection of any religion it is an addition, enrichment to their previous religion.

The importance of the above theories to the thesis relate not only to the four causes of conversion but specifically Disappointment with the Church. Once there are restrictions applied on cultural behaviors by a religion, many people will realized that they are going to be deprived of certain cultural traditions. Many converts instead of relinquishing the previous religion before they convert they retain certain characteristics of their previous religion or others just practiced both as in the case of Haiti, Asia, India, Phillipines and many other places. The leniency of Catholic Church and the services provided in the country support the church in remaining the dominant religion for centuries. Religion occupies a large space in many people's lives especially in societies with socioeconomic inequality, political injustice and poverty. However, after the Church lost certain priviledges in the political arena the quality of services provided were greatly affected. Many people convert in search of a better or a more receptive environment in order to improve their economic status or their health. 
Eliade and Prichard's theory also explains that at times, people move out of their tradition for a time only to rediscover the tradition they left behind. There are many cultural traditions, festivities that take place year round in Haiti. At times, many converts participate in those activities, if caught they may be sanctioned from Church activities or some realized the tradition they left behind and revert back or chite ${ }^{4}$. As stated by Brodwin,

"The failure of biomedicine, herbal treatment, and prayers indicate that the illness of a young man with a promising future in Jeanty, a small town in Haiti was a 'maladi Satan." And the only way to take off the magic is a Lwa (Spirit). However, Lésage a resident of the village explained that this was unlikely to happen for the young man, because his family was Baptist and Protestants believe that prayers alone would work. However, upon the young man's death his family included a sènp ${ }^{6}$ in the coffin." (Brodwin 1996:105).

The family's reaction demonstrates that cultural traditions dominate religion. Vodou in Haiti is not only a religion, but also a way of life in certain parts of the country. The theory reiterates that failure of one religion to accommodate, to support, and to provide socially and/or emotionally will result to conversion or delay the conversion process where potential convert will either revert back or move on to another religion.

As people migrate, the struggle to retain cultural traditions emerged; immigrants maintain strong transnational ties with their homeland whether it is social, cultural, and

\footnotetext{
${ }^{4}$ An expression used in Haitian Creole when believers stop attending church services and activities.

${ }^{5}$ Maladi Satan —An "illness of satan" typically sent upon the victim by his/her human enemies out of jealousy or the desire for revenge (Brodwin 1996).

${ }^{6}$ Sènp- (Simple in English) Senps are used to protect the body against further depredations after death from a Maladi Mò (An illness caused by a spirit of a dead person sent upon the victim). Example such senps include placing a thread with an eyeless needle in the coffin, so when people come claim the body, they will become preoccupied with the fruitless task of threading the needle and eventually leave without taking the victim. Also other sènp can cure Maladi Satan before someone's death, and these are usually made from certain leaves or the page of a bible or other "magical book" (Brodwin notes 211).
} 
political. Transnational ties that immigrants maintain with their homeland greatly affect their religious practices (Min 2002: 27).

The framework of the thesis is as follows: Chapter one presents an overview of the study. It presents the significance of the study, important theoretical and causes of conversion. It also presents the sociological aspect of religious conversion from different cultures and the role of traditional religions in the conversion process as it relates to the topic in the literature review.

Chapter two presents an overview of religions in Haiti from the colonial times until today and their function in Haitian life. It uses census data to show the dominant religion and the gradual public acceptance of Vodou in Haiti and around the world. It presents the Co-existence between Catholicism and Vodou that began since the arrival of the slaves. The co-existence contributes greatly to the survival of the ancestral traditions in the rural and urban areas in Haiti. The phenomenon highlights conversion in Haitian society since colonialism and that conversion is understood through the previous religion, Vodou. This fact contributes greatly to the significance of the study. The chapter also presents Protestantism, a religion from North America which identifies with socioeconomic and political power. Its rapid growth and infiltration in Haitian society due to services provided accompanied with the ideology and evangelization that rejects Vodou and all of its practices have placed barriers in the society.

Chapter three presents Vodou in a historical perspective. Religion of the ancestors transported from Africa to Haiti as a result of slavery an aspect of Haitian culture and identity. It is the religion of resistance and resilience in Haitian society considered until today by many Haitians and outsiders as the religion of the impoverished 
and the cause of Haiti's misfortune. Vodou's deep seated roots in Haitian society contradict religious conversion in Haiti where converting to a new religion is viewed as an addition to the previous religion not a rejection. The chapter also examinesVodou as an important tool in community building in Haiti manipulated by many political leaders when in quest for power. The international community's failure to acknowledge the role of Vodou, religion practiced by the masses, in building democracy in Haiti has impeded the democratic process.

Chapter four will discuss the data from the study. The discussion will include interview data, quantitative analysis of the causes of conversion and the leading cause of conversion in Haiti. It analyzes the field work results, conversion across the waters and the importance of the forces of Vodou in Haitian identity in Haiti or abroad.

Chapter five presents major findings, the effect of religions, evangelization and religious conversion in Haitian society and the diabolic depiction of Vodou that has caused many citizens to live in fear of one another. Vodou is considered the "enemy" in part due to its renowned forces in community building. The chapter also uses the Ellison Model on Building the Inclusive Community/Discommunity to portray the Haitian society, the role of religion and Vodou in the society. Chapter five also offers the conclusion of the thesis. The conclusion will summarize the research design and methods it offers suggestions for future approach when conducting studies in Haiti. Following chapter five are relevant appendices: Definitions of Haitian Kreyol expressions used frequently in Haitian society. Religious congregations from Europe and Canada established in Haiti and Churches and Missions by departments. 


\section{Literature Review}

The research conducted for the study highlights the last decade as an "age of conversion" (Richardson 1978). Within the last decade the world has seen a lot of turmoil; since religion address human needs many people are on a mission to belong socially, emotionally and spiritually. The literary review will take into account benefits perceived by potential convert that triggered their conversion. Religions in many ways have provided support and institutional resources throughout the world (Kurtz, 1995). The literature will review the sociological aspect of religious conversion from different cultural perspective including the benefits perceived by potential converts as they related to the four causes of conversion selected in the study. In addition, the role of traditional religions in the conversion process without ignoring the psychological aspect. The study will refer to the transnationalism theory in order to explain the forces of vodou across the waters.

Protestant and Catholic churches provided services and resources mainly to atrract people (Min 2002), within those services provided there is an invisible struggle for souls. Bourdieu states that there is a religious competition, a mission to monopolize and modify the practice and worldview of the people (Rey 1999). However the effort to monopolize the worldview of the people has been a struggle for religions in Haiti. It is extremely complex to change people's beliefs, according to Robinson and Clarke because conversion is understood through social and cultural traditions which support Bourdieu's theory on religious habitus and the ambiguities in religious conversion in Haiti.

The research reveals that available literature specific to the causes of conversion from Catholicism to Protestantism in Haiti selected in the study and the role of Vodou 
after conversion is limited. However there is a massive literature available on religion, religious conversion, identity and Vodou. The study uses primary sources on religious conversion, traditional religions, culture and identity from the following literary work: Deita (1995), Eliade Evans-Prichard and Edward (1965; 1999) Lamb and Bryant (1999), Smucker (1984), Richardson (1978) Robinson and Clarke (2003), Rambo 1993; 2003), Rey ( 1999), Oddie (1997), (Massino 2006) for religion and religious conversion or Hourbon (1995; 2001), Demangles (1992), Bellgard-Smith and Michel (2006), (Metraux (1995), Bowen (1998) Consentino (1995), Mendoza (2003), for cultural traditions, Vodou and identity.

The change from one religous group to another taking place in such large number contradicts the usual approach to understanding conversion (Richardson 1978).

According to Anthony and Robbins, " research and related theory have concerned the assertion that recruitment to certain cult has been essential involuntarily in the sense that powerful techniques of "brainwashing" "mind control", or coercive persuation have rendered the process of conversion and commitment psychologically coercive and non consensual notwithstanding its formally voluntary status" (Anthony and Robbins 2004: 243).

As explained by many researchers conversion is an internal change, however throughout history, conversion has been triggered by external forces. The Jews in Medieval Europe, legal effort to convert Catholics to Protestants in Ireland, and the forced conversion of the African slaves to Catholicism upon their arrival in the New World. Such change is seen as relatively sudden and dramatic resulting in dimishing self esteem, increased dependency, and assumption of a new identity. The strategy employed in the conversion process has been used since the beginning of time; the idea is to subject converts to rigid loyalty and unquestioning obedience to the leadership (Anthony and Robins 2004: 244). 
In Haitian society "brainwashing"has contributed greatly to religious conversion. It is perceived as the achievement of a new religious self (Prichard 1965). Though switching from one religion to another may not necessarily lead to that conclusion.

William's James interpretation of conversion is categorized under a metaphorical understanding of psychological phenomena through sociological patterns. As quoted in many literary piece on conversion

To be converted, to be regenerated, to receive grace, to experience religion, to gain assurance, are so many phrases which denote the process, gradual or sudden, by which a self hitherto divided, and consciously wrong, inferior and unhappy, becomes unified and consciously right, superior and happy, in consequence of its former hold upon religious realities. This at least is what conversion signifies in general terms, whether or not we believe that a direct divine operation is needed to bring such moral change about (Massino 2004: 70).

The quote supports the process of religious conversion in Haiti where during the evangelization or "brainwashing" process descends an inferiority complex which led potential converts to believe they have been religiously mistaken all their life. This process is crucial when entering the new faith; it paves the way into the new religious community. During the process people are led to believe that their previous religion or beliefs caused them to alienate themselves from society and is responsible for all the struggles in their lives. They are led to believe that a switch from one religion to another will put everything in order. Since conversion is seen as a sudden and drastic change the decision made to switch from one group to another is based on emotion, religious affiliation or a moment of weakness and disappointment rather than a well thoughtout reasonable decision.

Throughout most of the twentieth century conversion has been studied from a psychological approach; however more recent studies have considered it in a more 
sociological term (Lamb, Bryant 1999: 2). In conducting research on religious conversion it is relevant to underline the psychological aspect of converts because the focus naturally bears on what transformations are happening in the psychological system of a person at a particular time (Massino 2004: 64). However, "psychological studies and test results of individuals before they joined a new religion are simply not available" (Saliba 2004: 327). While researchers have placed emphasis on the sociological aspect of religious conversion; "many psychologist are now looking at religion as an independent variable that can have positive as well as negative effects on human personality" (Saliba 2003: 319). Religious conversion for many people is not just a sudden change it is a quest of belonging, searching for meaning in their lives and/or spiritual stability.

In order to analyze conversion in Haiti, religion must be taken or explained in a societal context to facilitate the delineation of the causes of conversion. As stated by Massino, "study of religious conversion focus naturally rests on the transformation taking place psychologically because the structure of the mind is a result of the social structure and interactions" (Massino 2004: 26). The mind will react based on the environment and based on previous religious experiences. Richardson and Steward's further explanation on traditional conversion highlights conversion in Haitian society as it relates to time. "Traditional conversion has been viewed as something that happens once in a lifetime in either an abrupt or a gradual fashion at the same time, the person usually staying converted to the same perspective for a noticeable length of time" Massino implies that a sequence of time is not just a matter of disbelief or belief but the passage between them. Meaning relationship, religious group affiliation and personal events 
taking place in someone's life at a particular time may impact their decision to convert. When analyzing and applying Richardson and Steward and Bourdieu's theory to religious conversion in Haiti; it is important to take into account the noticeable length of time of the convert in reference to the new denomination or religion. The importance of the noticeable length of time relies on societal pressures and the failure of converts to follow the structural conversion process and whether or not convert turn to Vodou in times of personal crisis during the conversion process.

Durkeim and Prichard defines religion as a unified system of beliefs and practices relative to sacred things which unite into one moral single community called a church. The definition in all of its simplicity strengthens Vodou as a religion in Haiti. According to Fauerbach, religion is just a psychological device that people connect their hope, values, and ideals to an imaginary supernatural being called "God" (Prichard 1965). Religion may be just a device for some people; the fact remains some people rely on religion to establish meaning, comfort, and relief in their lives. Since religion answers to deep human needs, when one religion fails to provide answers or meaning, people move from one religion to another searching for relief. As Marx stated, to analyze religion or conversion within a culture, the social conditions and characteristics of human life in that particular society must be taken into account (Pals 1996). In Haiti a society where "diseases settle on the poor because they have been forced to endure hunger, famine, political violence and social inequality" (Walton 2006) benefits perceive by potential converts are important in analyzing religious conversion. To explain conversion in Haitian society is not implying that conversion in the society is not at all authentic; since 
the study is taking into account the sociological aspect of religious conversion the social issues affecting the Haitian society are discussed.

In Haiti it is important to realize the various meaning of conversion both across the religious tradition and even within a giving religious tradition (Lamb and Bryant1999:12). Taking into account the societal aspect of conversion, the complexity of the phenomenon in Haiti from Catholicism to Protestantism relies on the various practice of Vodou after conversion. In Haiti, where more than half of the population endure daily struggle, religion becomes an important aspect in Haitian life. There is a noticeable quest for meaning and answers whether it is personal, economical, sociological, political, and psychological that has been haunting the society.

The complexities of religions and religious conversion in Haiti have placed barriers in Haitian society affecting the development of the country. As stated by Rambo and Farhadian, "Understanding the dynamic forced field of converting person and/or group is a crucial step in the study of religious change" (Rambo and Farhadian 1999: 25). Poverty, unemployment, political, and economical instability, and many more factors affecting the basic needs in Haitian society have left the people with only one string to hold on to, religion. However, when one religion fails to accommodate the basics needs that followers rely on, many people on a quest to belong will convert from one religion to another, particularly in societies with African based religion as the case of Haiti.

The Catholic Church has been the dominant church in Haiti since colonialism according to censuses conducted from 1950 until today the largest percentage of the population is repoted as Catholics. After the war of independence which freed the slaves from oppression, Vatican removed all Catholic ties from Haiti and "Catholic priests, who 
were not concern with weaning the people away from the folk beliefs, permitted Vodou to root itself solidly within Haitian life" (Desmangles 1992: 51). The Catholic Church may seem to be lenient towards the practice of Vodou since the Second Vatican Council but that was not always the case. During the first United States occupation, the government outlawed the practice of Vodou (Desmangles 1992). Accompanied with governmental support, the Church conducted antisuperstitious campaign against Vodou; burning and destroying Vodou temples and paraphernalia. During the uprisings and strikes that led to the end of the occupation, the Haitian government took control over metropolitan medicine (Brodwin 1996). The government's controlled over the resources that provided the most basic needs for the society, and the decision of the Church to support the campaing against Vodou turned many followers away.

Before the signing of the Concordat $^{7}$, there were few schools serving the population. Fifteen years later, the Catholic Church owned $90 \%$ of the schools in the country (Appendix B). During that time the United States occupation together with the church responded to the basic needs of the society. The numbers of Catholics increased considerably from 1930 to 1972 (Desmangles 50:1992). The Church established programs benefiting a variety of technical skills and agriculture. The church's involvement in the improvement of public and private health reinforced follower's support.

In 1986 following the end of the Duvalier regime, Vatican removed its participation in Haiti and restricted Catholic priest from participating in politics in the country (Hourbon 2001). This decision splits the members of the Catholic Church. As a

\footnotetext{
${ }^{7}$ Recognition of the Catholic Church by Vatican in Haiti
} 
result the theology of liberation surfaced and many members left the Church due to the movement's association with violence. The absence of the clergy, an important resource in the community is reflected in the quality of services provided by the Church and the community. In the rural areas people walk miles to attend church service and the priest presiding over the mass is sometimes a visitor not a resident in the area. The role of the clergy is important in the community; it provides support for physical and mental health issues, individual, family counseling and confession ${ }^{8}$ an important activity in the Catholic Church. In addition, religious leaders may offer prayers at a person's home and provide support for love ones during difficult times.

Catholic education became questionable in a study conducted in Haiti in 2012 on Catholic formation and identity. Eventhough, one of the most important aspects of becoming a Catholic is formation through Catechism., catechism ${ }^{9}$ is not offered in $14 \%$ of Catholic schools, only $61 \%$ offer it at all grade levels and $40 \%$ of personnel are nonCatholics. ${ }^{10}$ The Catholic Church's inability to answer to deep human needs turn many to Protestantism.

Members of a church or congregation usually staffed the schools, hospitals and any institutions affiliated with that particular religion. Protestants churches funded by international organizations in Haiti have opened a number of services where only the church members are eligible for certain benefits. Since the government controls many

\footnotetext{
${ }^{8}$ Admission of sins

${ }^{9}$ A book that teaches basic principles of Catholicism; Prerequisite or preparation for sacrements (Baptism, communion, and Confirmation)

${ }^{10}$ Source: La Commission Episcopale pour l'Education Catholique
} 
institutions in the country, it is extremely difficult for one to ameliorate their economic condition. At times, one has to share similar religious tradition as the institution or the organization providing services when pursuing certain position in the community. A young Catholic woman in Jeanty ${ }^{11}$ said, "It is mostly the poor people who cannot do anything to better themselves, because they are poor, they are looking for God to help them. Rich people almost never become Protestants, they are well off, and they don't need God to give them anything" (Brodwin 1996: 185).

Evangalization targets the poor in Haiti, lack of knowledge and brainwashing have led many to believe that conversion is the way out of distress. Once the switch takes place and situation remains or worsen, many converts will continue to attend the current Church and continue to practice their previous or traditional religion. People are searching for answers and relief, and once one religion fails to accommodate their needs, followers will move from one religion to another.

Affiliation in a particular religious community offers social support and affective ties. At times it may provide the social and financial support needed for acute or chronic illnesses in Haiti (Rogers, Krueger and Hummer 2010). "Religious traditions advocate the importance of establishing and maintaining close personal connections, and in helping and caring for others" (Rogers, Krueger and Hummer 2010; Krause 2004). Congregation members may provide financial, emotional, and instrumental support for each other in the forms of loans, job-search, networks, transportation, help with house chores, and health care advice (Rogers, Krueger and Hummer 2010; Taylor and Chatters 1986).

${ }^{11}$ Jeanty-Town in Les Cayes 
A close relationship between an evangelist and a potential convert is a great chance for religious change (Rambo and Farhadian 1999: 29). Miguel Barrios is a poet who was guided by his aunt to convert to the Jewish faith, and then he moved to Brussels and Amsterdam where he led a double life: he would be a Catholic in Brussels then a jewis in Amsterdam with a different name (Massimo 2004). He was forced to hide his faith; many people in Haiti face a similar situation. According to Goffman, one presents different social masks even different beliefs within different social contexts in order to fluctuate within the society. The switch can be analyzed as a form of "destabilization of the self" which is when new religious ideas in the form of conversion provokes a destabilization of coherent structure of beliefs, which includes the personal and collective identity of a person (Massino 2004: 79). The moment of destabilization of self has been since early modern Christianity when persuasive instruments, verbal and visual were displayed in order to convert people to Catholicism.

"Critics have alleged that people are drawn into these movements through illicit methods rather than genuine conversion or conviction" (Bryant and Lamb: Intro). The Christian movement among the Kartabhajas a religious community of West Bengal in eastern India is an example of people who were drawn into the movement. In 1836, the leader and many others received baptism due to similarities of both religions. Two years later, the village was flooded due to heavy rain, since resources were limited; the missionaries only cater to Christians (Oddie 1997:61). The event turned many villagers toward the Christian movement. The Kartabhajas according to Derr in secret worshipped and followed rules of social behaviors, rituals which they had always practiced prior to their involvement in the movement. Similar in the southern region of 
the Archipelago (a chain or cluster of islands in the Phillipines) "the inhabitants embraced a major religion without relinquishing their traditional beliefs. The daily life of the common people is dominated by innumerable superstitions and beliefs which are foreign to Islam creed...having kept their pagan fathers and the bulk of the superstitions of the forefathers" (San Buenaventura 2002: 148). Syncretism is often limited to Catholicism, according to San Buenaventura, "for many Filipino Protestants believe in spirits and magic." The Kartabhajas, Muslim Filipinos, and Haitians have all "taken preserved precontact beliefs to be part of their new faith" (San Buenaventura 2002: 148) which supports Arthur and Bourdieu's theory on conversion. It is seen as adding a new culture to their existing cultures and the concept of total rejection of previous religion to embrace a new one is fictional.

In Haiti although many professed their conversion to Protestantism, in secret they still practice their Vodou rituals. According to Mendoza supporting Bourdieu's theory on religious habitus, "some converts take on their adopted tradition with rigorous adherence; others perform selectively, accepting only what corresponds to preexisting attitudes." In applying the following theory to religious conversion in Haiti one can detect the ambiguity since conversion to Protestantism in Haitian society means rejection of Vodou and all of its practice. In Haiti many converts revert back to Catholicism or/and Vodou because they realized they are not ready to keep up with the content of Protestantism and philosophy of Christianity and that they find religious elements in their previous religion more appropriate to their way of life (San Buenaventura 2002).

"Vodou in Haiti is a religion that, through complex systems of myths and rituals, relates the life of the devotee to the deities who govern that life. Like many religions of the world, it is a system of beliefs and practices that gives meaning to life: it uplifts the 
spirits of the downtrodden who experience life's misfortunes. In short, it is an expression of a people's longing for meaning and purpose in their lives" (Desmangles 1992: 2-3). In searching for purpose and meaning, disappointment caused many converts to switch back to their previous religion. In Haiti there is a saying that God has too many big things to do to be bothered with small stuff so whenever people need fast results they turn to the spirits. There is also the belief that the justice system only functions for the "elite" when people feel like that they have been taken advantage of instead of waiting for the justice system they turn to the spirits. Father Reginald mentioned that Vodou is very much part of Haitian identity, he conducted an experiment while writing his thesis in Ft.Lauderdale "I arranged a basket with different things and I placed it infront of the main entrance of the church. Without any exaggeration almost everyone turned around and entered the church through the other entrance. It is not because they practiced, it's because they believe and its part of them whether they want to admit it or not."

Transnationalism theory applied more often to the Caribbean and Latino immigrants as a result of the proximity and generally focuses on individual immigrant's transnational ties. However, studies have also focused on religious experiences in the organizational structure of a particular congregation in question (Min 2002: 28). There are other groups in the United States living transnational lives eventhough their homeland is not within the proximity for example Asian, Indian and Korean immigrants. As stated by Min, "Korean Christian immigrants preserve ethnicity by practicing Korean culture (not necessarily Christian rituals)"; Similar to Haitians in Miami who preserve their ethnicity by practicing Haitian culture which is not necessarily (Vodou rituals). To defend Vodou within the context of transnationalism is not implying that all Haitians 
practice Vodou rituals. However, there are aspects of the Haitian culture that are preserved abroad such as ethnic values, customs, holidays, food, dress, music, and dance (Min 2002:18).

Vodou gains most of its popularity in Haiti when it comes to healing. At times, people turn to magic to find treatment for chronic illness or illness caused by enemies. "Magic is not simply an aggressive act. The most common forms are by nature protective; protective magic is used to safeguard against illness and to protect gardens from blight or theft caused by human enemies" (Smucker 1984:45). According to Beauvoir, the head Vodou priest in Haiti, "Some Haitians believe that certain illnesses result from taboo violation or being disrespectful to elders, in this case the ailing person may try to "right" the "wrong" to restore balance instead of consulting a doctor for treatment" (Cook Ross 2010). Therefore many people remain Catholic due to its leniency towards the practice of Vodou, whereas Protestantism strongly rejects and condemns Vodou and all of its practice.

Including the factors leading to conversion mentioned in the study, failure of the spirits to respond to demands is also a major cause of conversion. Conversion to Protestantism does not only imply disappointment with the Spirits, but also "means of escaping ritual indebtedness to spirits" (Smucker 1984: 43). A woman's decision to joint the Baptist Church was influenced by a series of satanic illness (Brodwin 1996: 174). However, if conversion or medicine does not banish physical suffering, as mentioned earlier, it is a sign that, enemies send the illness. Moreover, the only way to cure this illness is to revert to magic. The controversy of conversion in Haiti rests in the healing 
practice and in the effectiveness of each religion. Once people feel that they are not satisfied, they will move to another religion.

Religion provides purpose and answers to human existence, especially in times of affliction. Failure of one religion to provide answers to its cohorts may result to conversion. The most illogical connection on religions in Haiti is the condoning of the practice of more than one religion in Haiti by Church elites, pastors, and missionaries; since religious conversion in Haitian society means rejection of Vodou and all of its practice, which supports Bourdieu's theory on religious competition. The struggle for souls existed in Haiti since colonialism. The idea of forcing people to accept a new religion and eventually take control over their mind without considering the effect of traditional religion has strengthened the traditional religions. The practice of Vodou by many people in times of need has placed Vodou as an intermediary between the different religions in the country. As the struggle for souls continue in Haitian society, the historical aspect and the co-existence between Catholicism and Vodou can lead one to believe that conversion endangers the social identity of a person (Massino 2004). In analyzing Massino's quote it can be seen or heard the mixed or confusing feelings many Haitians expressed about Vodou, a religion that promoted community empowerment during the war of independence.

Conversion is a controversial issue usually anticipated by many factors dominating a particular society. The following factors represent conditions under which people change their religion: frustration, rejection of traditional religion, self identification, family member, parent, significant other, high needs for affective ties and other basic needs such as food and shelter or an illness. In order to understand 
conversion in a particular society, the sociological aspect of it must be understood. In Haiti, both Catholic and Protestant ideologies reject Vodou, a religion practiced by the majority of the population; the rejection further contradicts conversion in Haitian society since Vodou is an aspect of Haitian culture. On the basis of the role assigned to Vodou in Haitian society the rebuff of the religion is a prerequisite for conversion. As people reject their culture, as stated by Massino, conversion may render the identity of a person vulnerable; which may have a negative impact on a particular society. The increased of Protestantism as a result of disapointment with the Catholic Church and lack of resources offered by the Church in the rural areas as opposed to the urban areas has had a major impact on the alienation of Vodou practioners; which hindered the development of the country. Furthermore, the misperception of the ancestral traditions, accompanied by the evangelization of the adepts surfaced an enraging hatred that has ruptured the Haitian society.

The Vodou religion was introduced into the Haitian society by the slaves during the colonial era. It was used as a form of community empowerment physical and mental rejection of European beliefs. Today those similar beliefs that were violently rejected by the oppressors during the colonial period remain the sole enemy of the ancestral tradition. Although Vodou has devoted servitors, many seem to apply its usage to their convenience.

The increase of Protestantism in the country, the failure of the Catholic Church in the socioeconomic aspect of the country and the evangelization labeling Vodou as the religion of "Satan" influenced greatly conversion in Haitian society. As the struggle to belong emerged, the rupture of the Haitian society surfaced. The separation has silently 
divided the country and hinders efforts on community building. Vodou remains in Haiti and in the diaspora a religion embedded in the daily struggle helping followers cope with life's suffering, a remedy in times of hardship, an important piece in the development of the country.

Even after Vodou has been given a reputable space in Haiti by political leaders; the religion of the ancestor's remains marginalized. As a result of negative connotation of the Vodou religion, accompanied by other factors dominating the society many Haitians develop a need for affective tie and converting from Catholicism to Protestantism according to many followers is the answer to the problem. However, as people leave their tradition, they realized the tradition they left behind (Lamb and Bryant 1999), during the conversion process many people faced with personal crisis such as illness, distress will return to Vodou. Since Vodou is portrayed as the religion of "evil" many people reframe from participating in the development of the country which impedes long term and successful consensus building in Haitian society. Protestants and Catholics ideologies may reject Vodou however, it is a religion deeply rooted in Haitian identity. One way or another, whether it is in the mentioning of a proverb, a song, by consulting an Ougan for a reading, or healing; all Haitians may not practice Vodou, but its existence and its powers are not denied. Its strength and its powers dominate religion in Haiti, and contradict religious conversion in Haitian life. 


\section{Chapter two}

\section{Religions during the Colonial time:}

\section{Catholicism and Vodou; Domination and Co-existence}

Columbus returned to Spain from his adventures in the new world, accompanied by a number of Indians. He believed that by evangelizing them, they would be able to return and convert the other Indians on the island. By 1496, the kingdom of Cacique Guarionex was evangelized. However, the inhuman treatment of the Indians and The Spaniards' attitude towards them quickly changed the minds, and hearts of many converts. Columbus then requested new missionaries to enter the island and evangelized the population with the intention to eventually convert them into Christianity. The Spaniards negative behavior towards the Indians and the small number of priests available on the island, made it virtually impossible for the Indians to even accept a religion.

Bartolome De Las casas, in his fervent role as the Indian's advocate portrayed himself to be to the devil's advocate. His passion for the freedom of the Indians, made him seem favorable to the introduction of the African slaves in the new World. The slaves transported from Africa to the new world originated from 21 nations. On the island of Hispaniola three nations from Africa represented in large number: Congo, Arada, and Senegal. European colonial powers, along with the Catholic Church, were fearful of the powers, which they saw the Voudouisant priests acquiring through their practice and rituals within the Vodou ceremonies. Their main goal was not only to persecute the slaves, but also the Vodou religion by exhausting every means available to them to be sure their mission to outlaw Vodou was a successful one. 
Upon the slave's arrival in Saint Domingue through the Atlantic slave trade, the execution of the African culture began. The Code Noir of 1865 by Louis XIV was introduced into the French colonies a set of sixty articles that was supposed to give the slaves humanitarian rights. In reality, the Code declared mandatory conversion of slaves to Roman Catholicism in an effort to dehumanize them and eventually assume a new religious identity. Gatherings of slaves' night or day, in order to prevent the practice of African religious traditions on the island were condenmed. The colonial powers, concern for slave's rebellion attempted to give the slaves a new identity by introducing them to Roman Catholicism, which was in France the official religion. By giving the slave new religious identities, the French felt that it would be easier to manipulate and exert their control. Upon the arrival of slave ships, the slaves were given new names; they were baptized into Roman Catholicism and further amended by European society and culture. Although the slaves had daily contact with each other, the ancestral cultures from which their members originated from were different in nearly every way.

The slaves did not share the bare essentials needed to form a society. They did not share a common language, or a single political system (Trouillot 1995). Unable to openly practice their ancestral religion the slaves found a way to connect with one another. During the seasoning when they all gather to meet with their masters to prepare for work the gathering coverered much more than intended. The slaves were able to establish a line of communication through their religious practices. Vodou in Haiti during the colonial period was a religion of unity it requires people to assemble. The assembly created a sense of community empowerment, a form of retention with their ancestral 
home. Thefore, they were not allowed to practice the religion of their ancestors; the only religion allowed to practice was Roman Catholic, religion of the colony.

The practice of all religion except Catholicism was forbidden; Le Code Noir classified the slaves as personal properties, leaving them no rights. Their words and gestures controlled and Christianity forced upon them left them lifeless. The justification of slavery fell on the Church (Hurbon 2001). Faced with these new set of rules, and torn from families and kinship groups, the slaves experienced a profound sense of alienation. They filled this forced isolation and emptiness by reaching to Vodou, which was practiced in secrecy for fear of being discovered and severely punished. Vodou was outlawed; singing and dancing were also forbidden because of their direct association with Vodou rituals. The slaves performed their ceremonies late at night when the plantation owners were asleep and there would be no way of discovery. The slaves were restricted to holding ceremonies in obscure locations away from the cities or plantation homes. They refused to abandon Vodou and would go to all ends to preserve their religion. The slaves used syncretism, and knowledge of different tribes, to unite and organize themselves on the road to freedom.

The relationship between Vodou and Roman Catholicism in Haiti dates back to French colonialism and slavery. Official rites of the Catholic Church, such as baptism, communion, marriage, and burial, are significant in Vodou cosmology. The worshiping of Catholic Saints and receiving sacraments served as a cover for the practice of Vodou during the colonial period. The slaves renamed the diverse family of spirits Nanchon; ${ }^{12}$

\footnotetext{
${ }^{12}$ Nations
} 


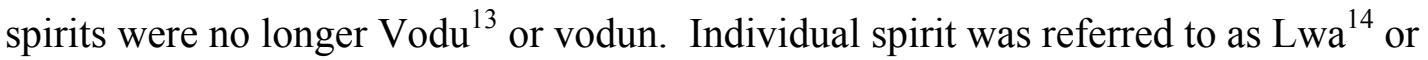

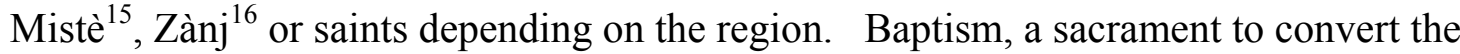

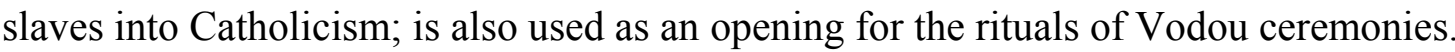

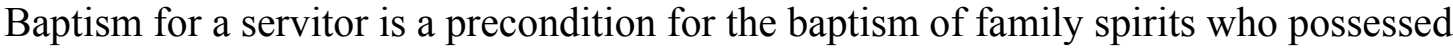

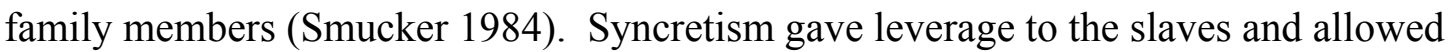

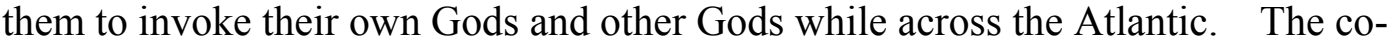

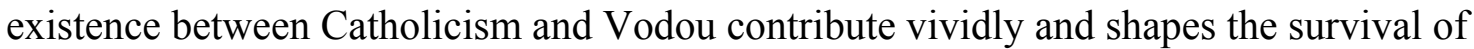

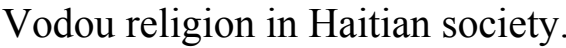

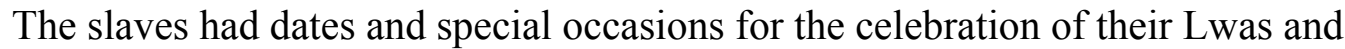

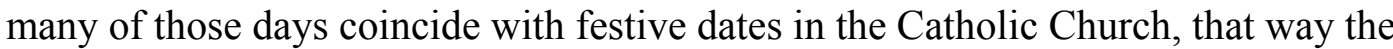

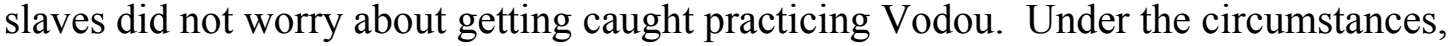

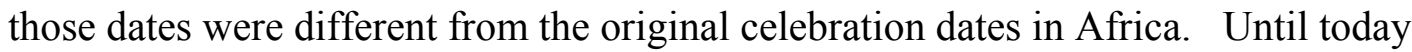

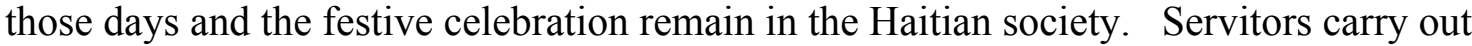

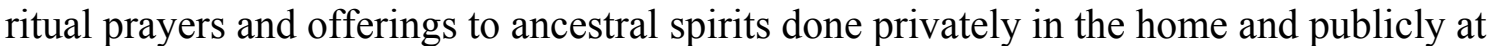

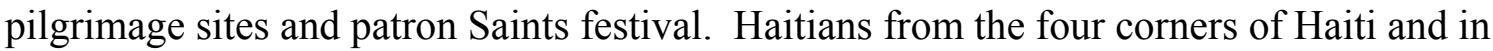

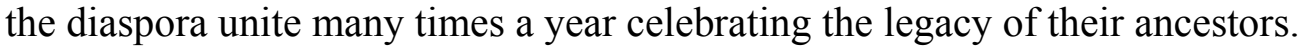

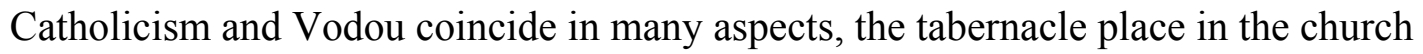

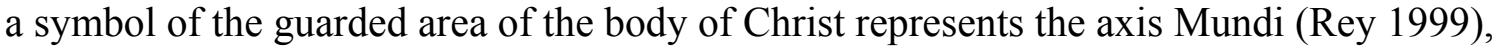

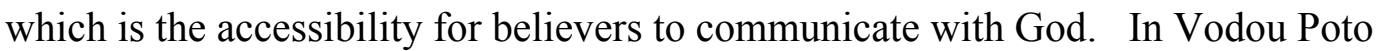

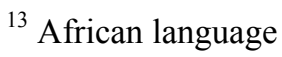

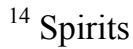

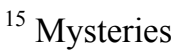

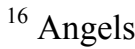


Mitan ${ }^{17}$ of a Vodou temple, represents a path through which Lwas are said to arrive, it also represents the connection between Grant $\mathrm{Met}^{18}$ and Earth. Many see sacrificing of animals in the vodou religion as malevolent. In the Catholic Church sacrifice is done in every ceremony; it is just a different type. According to Rey, in order to understand this connection one has to refer to Durkheim's theory on the Sacred and the Profane. When the priest lifts up the Eucharist in the church, it is a symbol of what is sacred and mysterious and animal sacrifice in Vodou is a symbol of what is profane and mundane.

In Vodou ceremonies, catholic prayers, saints, and symbols are incorporated without the approval or participation of a Catholic priest. For example while praying, the word "Saint" refers to Saints in the Catholic Church, in Vodou it also refers to inherited family mistè. Each Saint in the Catholic Church corresponds with a Lwa or spirit in Vodou (Table 1). In both situations of receiving Sainthood or Deity hood from Table: 1 Catholic Saints Vs. Vodou Spirits:

Saint Joseph: Papa Loko- head priest a healing doctor

Virgin Mary: Ezili Freda -Goddess of love

St. James Major (Saint Jak majè): Ogu Spirit of war, fire, and thunder Saint Michael: Ogu Badagri; Saint George: Ogu Balendjo; Saint. Elias-Ogu "Kriminèl'(Criminal); Twin saints: Cosmos and Damian, Saint Claire and NicholasMarasa;

Lady of Mount Carmel: Ezili Dantò

Saint Patrick of Ireland: Dànbala Wèdo -because of the snake imagery Saint John the Baptist with his ship:Shango: Lwa (spirit) of luck

Saint Peter: Baron (Has to key to heaven and Earth)

either religion, a person must have held an extraordinary life to have reached this status in their afterlife. In the case of Vodou the deities will possess very strong political

\footnotetext{
${ }^{17}$ Sacred center pole

${ }^{18}$ Referring to the higher being in the Vodou religion.
} 
revolutionary roles in life; many are great African warriors and as a consequence of their bravery, they have been awarded the position.

Vodou originated from Africa, went through a period of renaissance upon the arrivals of the slaves in Haiti with the fusion of tribes and other cultures on the island. The slaves from Africa to Haiti fused their different tribes, the Carib Indians ${ }^{19}$ and the freemasons who migrated from France and North America. Freemasonry recognizes only the light and not the bearer, which is a very common belief of African religions (Hourbon 1995). The Carib Indians connection to the sun, the moon and the land are similar to Vodou's ideology. The African's removal from Africa greatly affected them spiritually and personally, for many had strong bond with their land and felt that their ancestors may feel abandoned. They worship the land with the same enthusiasm as their Lwas. $^{20}$ The co-existence of the two religions on the island was also a form of survival an escape from death during the colonial era. Rebellion against Catholicism can also be observed in Vodou cosmology, "If Catholicism is identified with heaven, Vodou is associated with Earth" (Demangles, 178). Catholics will pray to God and feel his presence will guide them. Vodouisants feel that Bondye ${ }^{21}$ is too busy to deal with their petty human issues and has more important things to concentrate on; they turn to the Lwas for immediate results.

From 1804 to 1860, the presidents of Haiti controlled all functions of the Catholic Church in the country. During that time, the condition of the church in Haiti became

\footnotetext{
${ }^{19}$ Natives of the island

${ }^{20}$ Sprits

${ }^{21}$ God
} 
lamentable. The evangelization of the island rests on the hands of many foreigners chassed out of their archdioceses. Many of them were either not ordain as priests or they were fugitives convicted of serious crimes. In 1860 with the arrival of Protestantism and Freemasonry in Haiti, Rome signed a Concordat with president Geffrard recognizing Haiti as a Catholic nation. However, Vodou still remain the religion practiced by the masses in Haiti. The second Vatican Council in 1962 changed the vision of Catholicism in Haiti in comparison to the Colonial times. It allowed the Catholic Church to deliver the liturgy in Haitian $\mathrm{Kreyol}^{22}$ instead of Latin and began to integrate the Haitian culture in the church by playing Tambours. ${ }^{23}$ Before then, many people attended mass and had no understanding of the liturgy, for many their participation was simply a routine. Researches on religion in Haiti mostly take into account Catholicism, probably because of the large numbers of followers (figure 1 and 2). The data also states that half of the population practiced Vodou. According to Smucker, there are two different types of Catholics those who serve and those who do not serve the spirits. According to Bellegarde's relation of religious texture of Haiti to that of Japan "The same Japanese person will observe Shinto faith for certain rituals and Buddhism for other and will see no contradiction or mutual exclusivity" (Freedman 2010). In Haiti as a result of the marginalization of Vodou members publicly deny their affiliation with Vodou while practiced and used the forces of Vodou in secrecy. The constant struggle for the Haitian people to preserve their identity is one of many reasons why Vodou formed the deepseated roots in Haiti.

\footnotetext{
${ }^{22}$ The dominant language spoken in Haiti and among Haitian living abroad.

${ }^{23}$ Drums: one of the most important elements in Vodou rituals.
} 
The systematic separation of the slaves upon their arrival in Saint Domingue was a strategy for them to lose memories of their families, links to Africa, and their tribes. The strategies used disabled the slaves mentally and physically. The idea was to enable them to form a community and eventually assimilate. They were made emotionally and physically weaker hoping that this scheme would cause disputes and fights amongst the slaves where they would worry less about organized rebellion and disturbances. Eventually the slaves would then be easier to manage and primed for a life of total submission. However, Europeans did not consider the misery of slavery and middle passage would incite a common thread of faith among the Africans. The thread was what held the African people together in times of need, suffering, and utter desperation. They would take refuge in Vodou to survive the trials and tribulations on an unfamiliar land. As the years progressed and hopes of returning to their homeland dwindled, the slaves began to cling to Vodou as their salvation. Even with so much at risk if caught practicing Vodou the slaves continued with their defiance. Looking through the eyes of any enslaved society, once people began to live under the impression that they have nothing to lose, they will ultimately begin to risk the little they do have.

In the case of the slaves in Haiti it was their existence that was put in question. It was not about giving up their ideology, which sustained them and gave them power and strength during their arduous journey, but rather tp what means would they go to preserve their culture, and identity. It is seen through the sheer determination of the Haitian people that would put their lives on the line time and time again, if it meant fighting for their personal beliefs. It is in the context of being violently torn from their roots, having their every move controlled, and above all having Christianity forced on them that the 
slaves tried to resume their cultural and religious traditions, which represented a force of survival that was at one time individual, but grew to be collective toil. It has been widely argued by historians that Vodou played a crucial role as an inspirational and unifying force for the slaves in the Haitian revolution. Such a consolidating agent was especially needed to the struggle's success since more than half of the colonies' slaves who took part in the revolution were born in Africa. In Saint Domingue, the slaves kept their old religious traditions alive in secrecy. Vodou was such an organizational force in the revolution, that Haitian intellectuals have to this day praise the famous dictum of Jean-Price Mars, “1804 est issu du Vaudou”24 (Desmangles1992: 36).

Writers such as Haitian Catholic priest and historians of religion feel that in general,

"The Haitian historians and ethnographers, especially disciples of Price-Mars, may have underestimated the role of Catholicism in the acquisition of independence in Haiti. They argued that Boukman led ceremony at Bois-Caiman alone could not be accredited for sparking the revolution. It was a mixture of Vodou and Catholicism that brought about the independence of Haiti because there were other revolutionary leaders successfully syncretized both Voodoo and Catholicism to influence the slaves to revolt" (Désmangles 1992: 39).

The quote should be scrutinized based on the fact that there was a consensus between the slaves to organize and free themselves. The compromise was made during the time when they were evoking their spirits from their homeland. Furthermore, Roman Catholicism was the religion of the master forced upon the slaves and punishable by death if caught practicing Vodou. The slaves had to mask their worshipping and pretend as if they were practicing Catholicism. In that sense syncretism during the colonial era

\footnotetext{
${ }^{24} 1804$ was issued from Vodou.
} 
was a form of escaping punishment or worst death. Catholicism unintentionally was used as safeguarding or for the survival of the ancestral religion As a result of outlawing the Vodou religion it took on many symbolic characteristics of Christianity. By the time the Catholic Church regain contact with the nation, Vodou was spread with the combination of Christianity.

The two religions have been portrayed at times as widely held belief systems. The slaves practiced both religions at the same time to accomplish the same purpose. The Vodou religion does not have any strict laws regarding practitioners following other religion or praying to other Gods, the assimilation became quiet easy. "Choked by oppression, the slaves were obliged to hide their secret adoration of obscure forces to which they themselves tied by long ancestral traditions" (Desmangles 1992: 11). The slaves invoke ancestral spirits and Catholic saints, and recite Catholic sacraments as a form of support an effort for survival of their African beliefs in a foreign land.

The interplay between the two religions forms a social integration, which would affect Haiti in a number of significant ways. The interaction between Vodou and Roman Catholicism has cooperated in a way that both religions became unique to the island. In spite of all efforts to nullify and falsify Vodou, it has survived throughout the ages not only in Haiti but also in other islands within the Caribbean. Vodou prescribed practices by which an individual might or could perhaps attempt to influence the spirit world in his or her own behalf. For that matter, it is very easy for someone not knowledgeable of the Vodou religion to see aspect of it and have a complete Western biased outlook of the religion without ever getting to know the intricate workings of Vodou. Regardless of the opinions regarding the subject, Vodou in Haiti was mainly introduced during the time of 
slavery as a sense of community empowerment that allowed the slaves to have hope of a possible liberation from their state of oppression. Today Vodou remain in Haitian society the religion of resilience. 


\section{Chapter three}

\section{Modern Colonialism brings a new Religion: Protestantism}

Henry Christophe, king of the North side of Haiti considered the advice of Charles Clarkston an English abolitionist of Protestant faith to evangelize people in the country sides. After Christophe's death, Boyer succeeded in unifying the island and created an inviting atmosphere for the English immigrants and untied the path for other religions pertaining to the Protestant movement. Protestants introduced themselves in Haiti by building schools; which is one of the ways to be accepted by the Haïtian government. John Brown and James Catts arrived in Haiti and took part in establishing an education system (Fontus 2001). They established themselves in the North and the South of Haiti, mostly in big cities like port-Au-Prince. The small percentage of the population recorded as Protestant in the rural areas comparing to the percentage of Catholics contribute to the survival of Vodou in the rural areas (figure 5).

Figure: 5

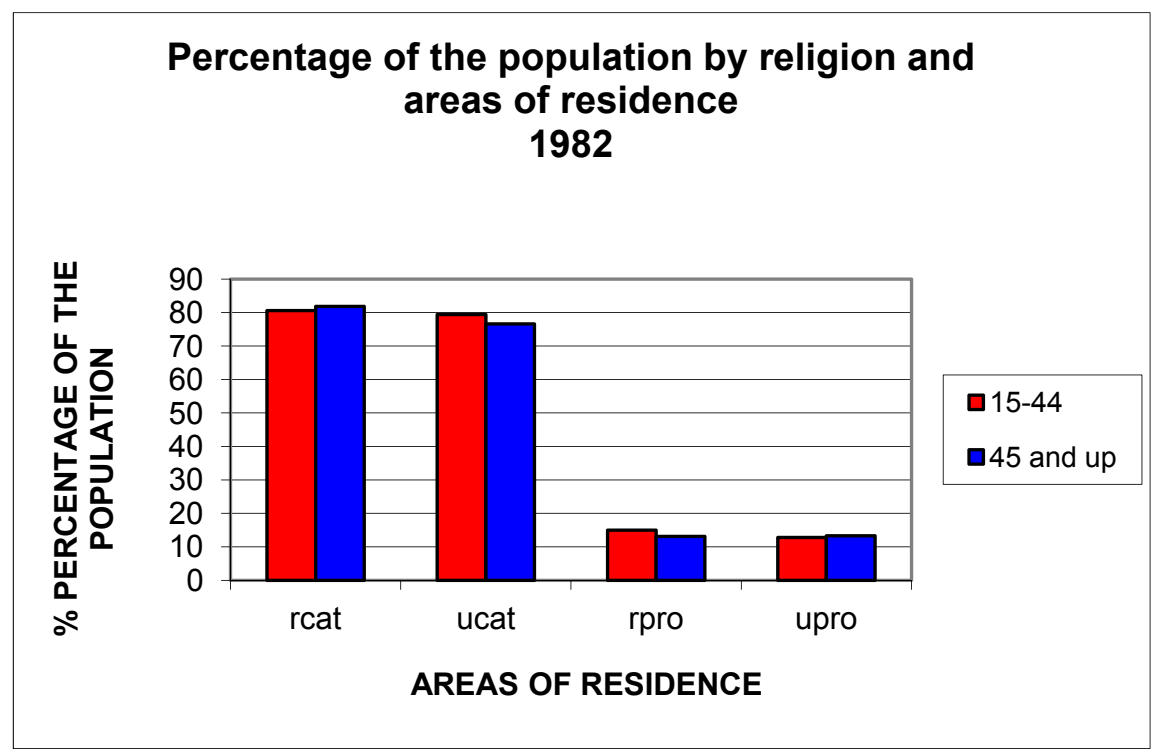

Source: IHIS, Recensement General de la Population: Census 1982 
According to the Protestant Federation of Haiti, the mission of Protestantism includes "expressing the unity of churches, promoting evangelical and social activities in Haiti and in the Haitian communities abroad, so that each one of its members may become an effective agent of reconciliation." Protestantism has provided social services such as education and hospitals for the youth and the poor. In the last decade Protestant population in the rural areas has increased. The growth may be explained by the large number of Churches and the accessibility of the missionaries to evangelize the population. Futhermore, Construction of many hospitals, clinics, and schools accompanied by missionaries receiving help from abroad has influenced conversion in the countryside (Appendix D). According to father Reginald, "In my hometown in Jean Rabel, rural area in Haiti, pastor Wallace built the biggest and the most beautiful church with lights and music, movies in the village at nighttime; things that people have to travel far to see. The appearance of the church, missionary aid from abroad providing food, clothing, and more began to attract a lot of people where some eventually convert to Protestantism.”

As I will explain further the unity of churches, part of the mission of Protestant Federation in Haiti cannot be seen throughout Haiti or in Haitian communities abroad. The first Protestant Church established in Haiti was the Methodist Mission from England and created L'Eglise Methodiste D'Haiti ${ }^{25}$ established in the cities (Fontus 2001). The Protestants churches and its followers in Haiti have been growing immensely and contributed greatly to the socio-economic life in the country. In comparing the number

\footnotetext{
${ }^{25}$ Methodist church of Haiti
} 
of followers in the ninetieth and the twentieth century the number of adepts doubled in the twentieth century (figure 6). During the last forty years Protestantism increased Figure: 6

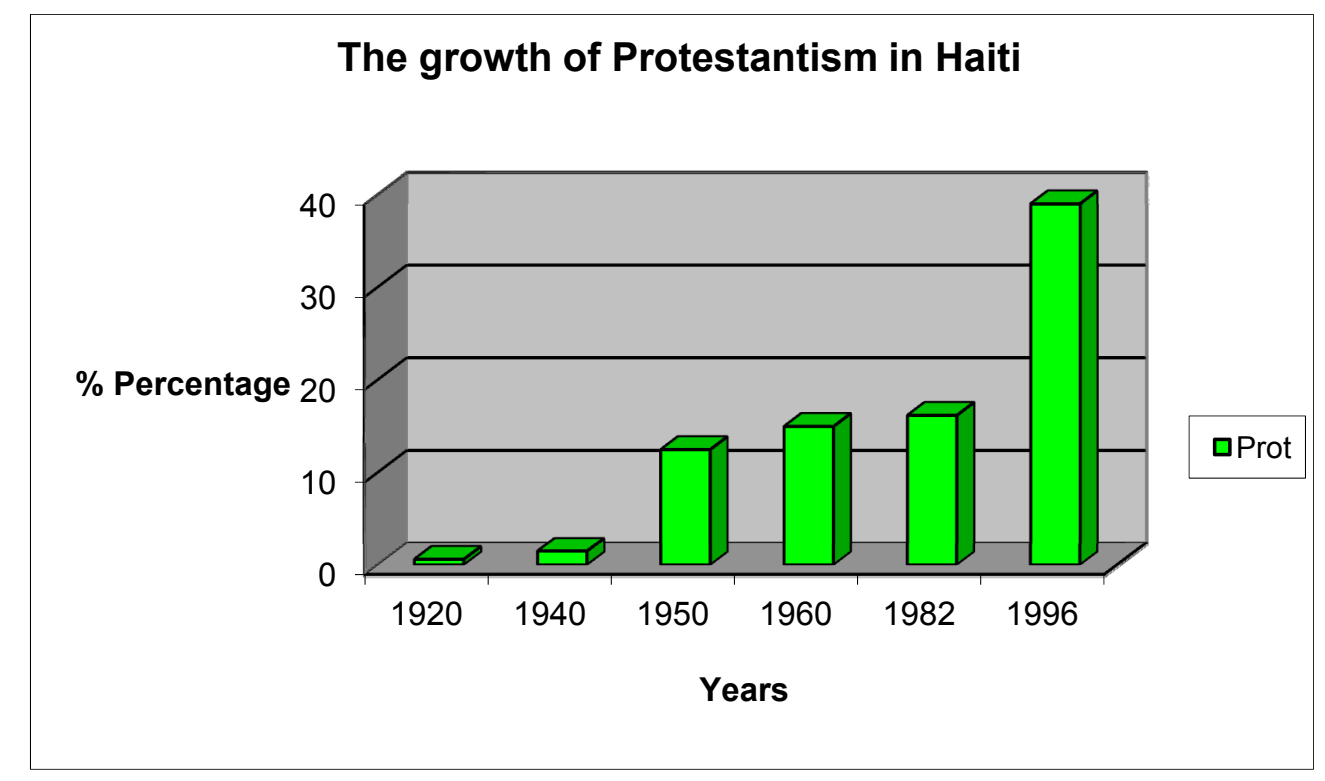

Source: Les Églises Protestantes en Haïti: Communication et Inculturation.

by $4 \%$ every 10 years and has been increasing since. In 1996 Protestants represented $39.0 \%$ in 1997 similar research has shown that $25.7 \%$ of the rural population was Protestants (Fontus 2002: 89). In less than forty years, around 40\% of the rural and urban population in Haiti became Protestant. Protestants churches in Haiti have been successful not only for the numbers of adepts attracted in the country but also the services they have provided and their contribution to the socioeconomic life in the country. Protestantism attracted mainly the middle and the upper classes, and it played an important role in educational life. People in joining the Protestant denominations are seeking amelioration of socioeconomic life through an inner change. 
Religious conversion, a drastic change from one religion to another, is not always based on faith nor is it always an internal change. The change may be interpreted according to the lifestyle in a particular society. According to Fontus, when converting, people should experience a radical change in their lives and they should feel comfortable in their culture that will also help them contribute positively to the development of their country (Fontus 2001). Unfortunately in Haïti that is not always the case, in the early part of the history of Haiti; Protestants on the island excluded themselves from the development of the country. They often separate themselves from the rest of the society meaning the Catholics, the Vodouisants, in sum the state. For them, the isolation enables them to perform better the task assigned by God.

Protestant ideologies reject Vodou, the religion practiced by the masses in Haiti. The rejection withdrew many from the development of the country. In Haiti, where the masses are hopeless, it is crucial that churches (Catholic, Protestant, and Vodou) take responsibility in organizing and building the society. For years, the church in Haiti either support the state of oppression under which the masses is struggling or completely ignored or is reluctant to state its position against the political, and social exploitation and injustice around the country. According to Casseus, religion in Haiti cannot remain silent especially when it comes to the exploitation of human beings, it must not only denounce the injustice but also serve as a mediator in the socio political arena. Recently Protestants begin approaching slowly in the political arena in Haïti. Certain pastors via the media have declared their position or even took part in a political party. In the history of Haiti, Protestants would criticize the oppression of the poor but would not publicly participate in the political crises in the country. 
In the $21^{\text {st }}$ century missionaries need to realize that in order to evangelize or deliver a message to a group of people, socially, culturally, religiously, and economically, they must be in harmony with the group. Throughout the history that has been told about Haït, since after the war of independence, Haitians have always been divided. However, the literature has not focused on one of the major causes of the division; different religions on the island. As the branches of Protestantism expand in the country, Protestant leaders began to emerge and involved themselves in the sociopolitical affairs of the country. A group of pastors condemned the cruelty of the regime with the help of the media. Radio Lumière ${ }^{26}$ a Protestant radio station reiterated that the pastors involved in the signing of the declaration were not reacting on behalf of the Protestant community (Fontus: 110-113). The dissociation of Radio Lumière with the pastor's position against the regime at the time allows one to reach the conclusion that the group of pastors reacted as individuals but not as representative of the Protestant community in the political arena. Historically Protestantism isolates from the political arena in Haiti. The evangelization of the adepts has caused them to segregate themselves from all "evil" such as Vodou including Catholics that makes up more than half of the population. The religious segregation in the country have contributed greatly to the under development of the country.

Many people inside and outside of Haiti have blamed Vodou for the country's downfall; they fail to realize that Vodou is an open dynamic religion. It welcomes everyone regardless of age, sex, creed, color, social class, and acceptance of one another with their differences (Michel 1995). After the killer earthquake in 2010 that claimed

\footnotetext{
${ }^{26}$ Radio of light (enlighten radio)
} 
the lives of thousands, Pat Robertson declared Vodou responsible for the natural disaster. He claimed that, the rebellious slaves' pact with the devil to overthrow the French is the cause of Haiti's misfortune. His claim raised an important question on the ratification of slavery, will the French be punished for tearing people away fromtheir homeland and subjected them to a lifetime of servitude? Many confessed that religions in Haiti have contributed greatly to the under development of the country. Their arguments based on the fact that Protestantism and other religions with help coming from abroad entering Haiti have a great impact on the people's efforts to become self sufficient.

It is very common in Haiti to blame Vodou or each other for the downfall of the country instead of facing the real issues. Under development is viewed by many as a result of worshipping spirits and converting to a modern religion such as Protestantism offers a prominent solution for a prosperous life. The next question should be How come poverty still exists around the world even in countries without spirit worshippers or Vodou? Vodou according to Protestant ideology is the religion of Satan. The survival of the ancestral religion can be analyzed as form of rebellion against Christianity. Haiti's assigned labeled as an "uncivilized society" is a result of its religious beliefs that differ strongly from the rest of the world. The mission of Protestantism in Haitian society involves transformation of its members as effective members of reconciliation. However, evangelizations of the adepts have placed barriers in the society, instead of reconciliation one can observe religious segregation developed out of misperception of self identification. In evangelizing the population, Protestants appear to offer relief from the evil and the suffering world only in the afterlife; (Casseus 1993) in contrast to the people of Haiti who are searching for relief on earth in their everyday life. The rapid increased 
of Protestantism in Haiti may not necessarily lead to an internal change. According to Deren, if Protestantism does not "satisfy actual needs that serves the organism as well as psyche; serves as practical methodology, nor as individual hope" (Desmangles: 5); people will continue searching for meaning in their everyday life until they find a place to belong. 


\section{CHAPTER FOUR}

\section{Religion of Resistance and Resilience: Vodou}

It is difficult to give Vodou a valued space in Haitian society. It has been publicized, commercialized, exploited and used to provoke fear inside and outside of the country. In order to explain Vodou the study must differentiate between Voodoo that is known as solely magic and Haitian Vodou that is an aspect of the Haitian culture and deeply rooted in Haitian identity. The origin of Vodou is a controversial issue. The rationale behind the controversy lies on whether historians date Vodou with the start of the French colony Saint Domingue or back to Africa (Laguerre 1989). On the continent of Africa the religion was not called Vodou, instead; it went by many different names. The word Vodun comes from the West African Dahomean meaning spirits or deities. Ougan, title meaning spirit chief or bocor derives from bocono, meaning the diviner or priest of Dahomean Fa cult (Laguerre 1989: 25).

Vodou is the integrated beliefs from many African cultures such as the Fon, the Nago, the Ibos, Dahomeans, Zaire (formely the Congos), Senegalese, Hussars, Caplaus, Mondinges, Mandinge, Anglose, Libyans, Ethiopians, and the Malagaches. Although, these cultures varied, they shared the same basic religious, magical beliefs and practices born of similar geography and living conditions. Some scholars estimate that the Vodou tradition is over 10,000 years old. Doctor Holly has placed its existence since 3600 B.C. (Deita 2001). It is a derivation of the world's oldest known religion, which has been in Africa since the beginning of human civilization.

According to Laguerre, a Jesuit missionary Pierre Francois-Xavier de Clervaux stated that many countries in Africa provided slaves among them were: The Senegallois, 
the Bambara, the Aradas, the Congos, the Nagos, and the Mondongos (Laguerre 24).

The three largest groups were the Sudanese, Guineans, and Bantus (Hourbon 1993). The most influential was the Fon tribe of Dahomean, combined with the Yoruba and Nigeria. They provided the unifying basis for the ensemble of cultural practices transplanted to the island by the slaves (Hourbon 21). Among them were: priest, priestess, healers, sorcerers, herbalist, midwives, soothsayers, and ritual assistants, craftsmen, such as drum makers, musicians, and criminals (Trouillot 1995). Although the African slaves transported their knowledge of the Vodou religion to Haiti, the Vodou practiced in Haiti differs from Africa as a result of the integration of other elements on the island of Haiti during the colonial era.

Haitian Vodou mainly inherits its origination from Benin, then from Bantu, Togo, and Cameroune. The slave population in Haiti needed comfort to deal with their state of oppression. While in Haiti, the religion became a mixture of many different ideas of the African tribes and cultures, Carib Indians, Freemasonry, and Roman Catholicism. The Vodou practice in Haiti contains two rites: Rada and Petwo. Rada originated from the kingdom of Arada is the foundation of Haitian Vodou. Petwo emerged in Saint Domingue $^{27}$ during the XVII century as a result of oppression, suffering, anger, and frustration from slavery. One can conclude that Vodou in Haiti although deeply rooted in Africa was born again in Haiti upon the arrival of the slaves. Bruno a Haitian Pasteur said, "Vodou the traditional religion in Haiti is a giant" (Fontus 200: 67). While the official religion in Haiti is Roman Catholicism; a large number of Haitians living in Haiti and abroad practiced Vodou. While Haitian intellectuals all agreed that Vodou plays a

${ }^{27}$ Present day Haiti 
role in the Haitian revolution, in Haitian life, and that its practice dominates the society; Vodou has never received the respect that it deserves. In the instruction manual of the 1971 Haiti's census ${ }^{28}$, religion is defined as follows:

- Spiritual or religious tendency or belief, whether or not this belief is represented by an organized group.

- Affiliations with an organized group that adhere to well determine religious or spiritual beliefs.

The absence of Vodou in Haiti's past census reflects the sense of discomfort that the negative publicity has developed in Haitian society (Figure 1). In the questionnaire, Vodou does not even appear as the "other" category. The manual specify the groups that should be considered as "other:" Jewish, Muslums, Jehovah witnesses, and adepts of the Anglican Church (census 1971). In the 2000 census, Vodou was included as a religion in Haiti. Finally, in 2003 president Aristide's decree legalized Vodou by granting the religion the rights to perform marriages and baptism in public and that those sacrements will be recognized by the state.

In an interview with father claret the bishop of Plaine Du Nord (neighborhood in Cap-Hatien) a parish known for its dynamic religious syncretism (Sen Jak Maje) ${ }^{29}$ he stated that,

"How many people will actually go and get married infront of a Ougan? Maybe in 20 to 30 years from now it will take a long time for Vodou to come out of secrecy. He goes further to explain that the strength of Vodou relies mostly on its secrecy and once it is made public people will not be able to find the miste ${ }^{30}$ anymore. Futhermore, baptism in the Catholic Church is related to a stage in Vodou; even if Vodou is official the mixture is still needed for a certain rank in Vodou."

\footnotetext{
${ }^{28}$ Department des Finances et des Affaires Economiques Institut Haitien de Statistique Instruction Manual 1971)

${ }^{29}$ Saint James (known as ogou in Vodou cosmology)

${ }^{30}$ Mystery, spirits
} 
Pastor Phillipe, former Pastor of the Wesleyan Church in Cap-Haitien ${ }^{31}$ also commented on the decree, he replied that Vodou has a long history in Haiti however Vodou is something that has always been behind close doors. After 1986, president manigat talked about Vodou on television, the first marriage performed in vodou was conducted in March 2003, and we can see the progress and effort of Vodou from 1993 until today. He implied that Haitian people are superstitious by nature and that the decree will make them even more superstitious."

Ever since the colonial era, Vodou's reputation contributed greatly to the confusion in the mind of many and it is portrayed and seeing as solely magic and witchcraft. In all religious phenomenons there is a religious aspect and a magical aspect. (Fontus 2000: 15-11). According to pastor Phillipe, Vodou has different aspects, therapeutic, medicinal, and also malevolent. Furthermore, magic is a concept that humans have created in order to obtain by force their demands from their superiors. For example, Catholics who burn the toe of a saint, and commit blaspheme when their demands have not been met or when they take the Eucharist received from the priest in a handkerchief and take it to a boco to perform magic. Protestants when they are ill who drink a potion prepared with a page of the Bible and those who recite Psalms especifically psalm 35 against their enemies are all performing magical rites (Fontus 2001: 70).

Since the values of the Haitian people are constantly being measured according to the opinion of others, the focus of Vodou has always resided on the aspect of sorcery and magic. Sorcery is universal; Shakespeare in McBeth describes a ceremony initiated by witches. Sorcery was invented by the inquisition, absolute political power and repression by the Catholic Church during the $12^{\text {th }}$ century. In England sorcery is not

\footnotetext{
${ }^{31}$ Second city in the country, located in the North of Haiti
} 
against the law; Charroux R. reported that during World War II, 800 sorcerers put their powers together with hope that Hitler's army would not invade their country. In the United States there is a superstition that the number 13 is considered evil, in hotels $13^{\text {th }}$ floor is nonexistent. Superstition, sorcery, and magic are neither Haitian legacy nor invented by the practice of Vodou. Negative connotations and constant denigration of Vodou caused many people to publicly deny their affiliation (Figure 5). In a study done in Port-Au-Prince, Haiti's capital, reveals that in the suburbs of Port-Au-Prince, $49.6 \%$ of the interviewees acknowledged being catholics $39 \%$ are Protestants, only $3.5 \%$ admitted to practicing Vodou (Hourbon 2001: 122).

Figure: 7

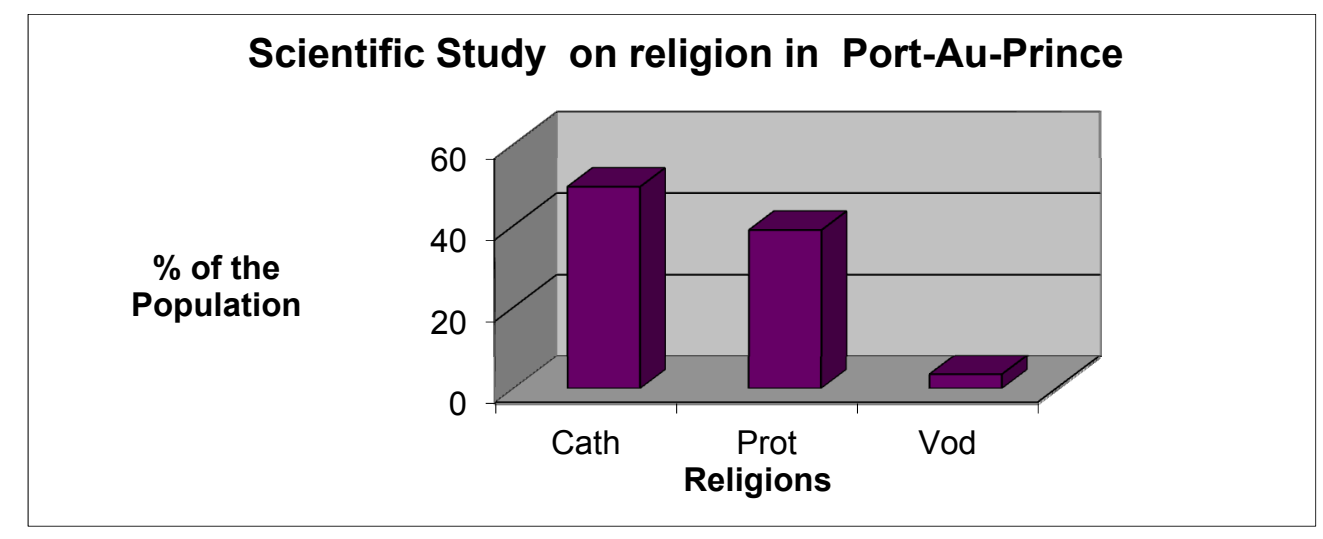

In conducting research in Haiti, although a significant number of the interviewees have agreed that vodou plays a role in their history, many have also expressed that Vodou is to blame for the troubles in the country. One can only be sympathetic toward this remark; many of them are only repeating a sermon from Sunday's service. In a Vodou ceremony many people find their sanctuary, especially in the dance one can observe the relief in the movement of participants, the freedom, and the confidence, the unity of Vodou priests or priestess to interpret messages or to heal. The festivity of Vodou 
ceremonies by the beating of the drums, dancing, spirit possession, and animal sacrifices are offered to the Spirits or deities to win their protection or secure material wealth. Haitians in Haiti are living under a state of oppression, injustice, insecurity and fear of dominant groups. Many adepts find answers to their sufferings, to their unanswered questions, and their reason for living in Vodou.

Just like leaders of other religions have their role within their congregation, in Vodou leaders also have their role. Though anyone may attend a Vodou ceremony, the responsibility of an $\operatorname{Ougan}^{32}$ or a mambo ${ }^{33}$ is keeping faithful relations with the $\mathrm{Lwa}^{34}$ by interpreting their messages. They have to be good medicine man or woman. Without warning the spirit may come in the body of any faithful individual, while in possession that person becomes the "horse" ${ }^{" 35}$ of a spirit. An individual possess by the spirit is subject to accomplish anything that the spirit desires. The planning of a Vodou ceremony varies; some cost more than others depending on the Lwa. ${ }^{36}$ It is said that many convert to Protestantism mainly as a result of the debts to the Lwa or as a form of divorce, rejection of purchased Lwa or inherited family spirits. In times of personal or communal crisis they may turn to Vodou for help. Vodou became for Haitians, as it has been for the slaves in saint Domingue, their explanation of life. While many converts hope includes disassociation with the Laws others cling to the Lwas as their reason for living. According to Michel, in reverse from the ideas that have divided the Haitian people,

\footnotetext{
${ }^{32}$ Vodou Priest

${ }^{33}$ Vodou Priestess

${ }^{34}$ Spirits

${ }^{35}$ Message carrier

${ }^{36}$ Spirit
} 
Vodou can help Haitians find similar values that united them before to unite them again around a common project of national reconstruction (Michel 1995).

Even after the slaves have struggled to preserve their culture to ensure that their posterity remained in a world with an understanding and knowledge of their origin, certain intellectuals and the Catholic Church by supporting the antisuperstitious campaign portrayed a sense of retaliation, impertinence to the culture and even the race. For many intellectuals and the Church the antisuperstitious campaign was a route to lead the people to civilization (Nerestant 1994: 125). The irony is if their customs, religion, thoughts, ideas, language and gestures were being monitored and even restricted; one can only contemplate on the civilization path expected to undertake. Many "intellectuals" have expressed that Vodou is the reason for Haiti's underdevelopment in order to cope with the inferiority complex that have caused them to publicly deny their African identity and embraced Western and French civilization (Nerestant 1994).

In Haiti, considering the state of oppression, poverty, division, discrimination, injustice, exploitation that the people are constantly being subjected to, religion in Haitian society must play a much stronger role than intended. Vodou plays a crucial role in politics, morals and health in the country (Hourbon 2008). In the history of Haiti politician have used the power of Vodou to gain popularity with the masses. "Vodou provides a system of belief, a way of life a religion embedded in its follower's daily existence and in their struggle for survival. It regulates chaotic actions and social behavior in Haitian society. It provides Remedy for ills help in times of hardship and support the welfare of community believers to deal with life suffering and pain" (Michel 2006: 30). Vodou's deeply seated roots in Haitian culture cannot be easily deracinated; 
its contribution to Haitian society shapes religious identity and contracdict conversion from Catholicism to Protestantism in Haitian society.

\section{Religious Manipulation: Vodou and Politics}

There is no sector in Haitian society that has over used or over exaggerates the powers of Vodou like the government. Political and economic decisions and outcomes in the Vodou religion are not necessarily held to a seperate standard, thus giving a popular religious or political leader great amount of personal leverage. Therefore, the Haitian culture had preset a society that would allow a leader that practiced Vodou; Duvalier "Papa Doc" elected in 1957. He knew that Vodou was more than a religion or popular healing practices in Haiti; he realized that Vodou for Haitian people was their worldview. He was the first national leader who no longer condoned Vodou and its practices but instead legitimized it. Though a relatively objective understanding of Vodou, Duvalier was able to strategically craft his position within the religion without fear of personal consequences. During Duvalier's (Papa Doc) presidential campaign, he was sympathetic towards Vodou practitioners. His position towards the followers of Vodou caused his unpopularity with the Catholic Clergy.

Vodou in Haïti although practiced by many is considered a religion of peasantry and of the lower class. During Duvalier's struggle for power, the Catholic clergy was preaching the people not to vote for Vodou meaning not to vote for Duvalier because of his support towards his ancestors. The Catholic clergy's anti-Duvalist campaign actually gave him leverage into reaching his goal. The bashing of Duvalier due to the religion practiced by the masses motivated voters. The Catholic clergy's negative's campaign against Duvalier because of his knowledge in the subject contributed greatly in his 
success in obtaining power. The church's anti-Duvalier campaign does not only show rejection of African roots in the culure, but also its influence on national politics during the wars of independence (Nerestant 1994). Duvalier did not present himself as a Vodou candidate. According to Laguerre in a speech he delivered in Port-De-Paix ${ }^{37}$ on March 19, 1957 "because my humble contribution to the study of some social phenomena deals with aspects of Haitian folklore, some people less informed in the domain of cultural anthropology have attempted to establish an insidious confusion between these phenomena which have been the subject of my studies and my religious convictions" (Laguerre 1989). As a result of his knowkedge of the forces of Vodou; he constructed his government to control the country in every aspect. He focused his organization based on the maroon communities that existed in Haïti during the colonial period. His implementation of Vodou in his political design strengthens his reign over the country for many decades.

The maroon communities were formed out of secrecy, meaning there is not a clear knowledge of the identity of who is actually a member; all members used secret codes, gestures to communicate with one another. The secret societies : Bizango, San Manman, Zobop, Vlinbindingue, San Pwèl, Nandinge in Haiti emerged out of oppression, fear, exploitation, insecurity and injustice as a mode of defense against the political powers, and dominant groups in the country that have routinely excluded the peasantry. The most popular one is called Bizango, they created solid bond that cannot easily be broken and Duvalier was aware of the solidarity amongst the secret societies, which according to Laguerre "is one way of understanding the makeup of the Haitian society"

\footnotetext{
${ }^{37}$ A town in the Northwest of Haiti
} 
by establishing links, they could stand as a strong underground government. Papa Doc was aware of their capability to overthrow his government. With no effort to beat them he joined them in order to fortified his power. Duvalier appointed an Ougan priest as the head of the national militia, and made Ougans all around the country part of his secret police force, Tonton macoutes. The Ougans reported directly to him and told him of any new Ougan priest that was gaining knowledge and acceptance within a particular community. According to Merrill foreign affairs attempts to build democracy in places as diverse as Somalia, Vietnam and Haiti have failed in part because of the developed nations' inability to understand the importance of local cultures in the design for a political reform.

Some researchers believed that Duvalier would have secret meetings in the national palace and hold Vodou ceremonies there. He allowed the practitioners to practice Vodou freely and they remained extremely grateful to him and his government. He was able to use the Vodou religion as an integral part of his program of repression and terror to hold his reign over Haiti. His manipulation of the religion for political power was very successful; holding power within the Vodou community meant holding power over the political destiny of the nation. After his death, his son married into the upper class and the abandonment by his father's followers mostly Vodouisants contributed to the downfall of the Duvalierist regime.

The next political leader who publicly recognized the forces of the religion was Jean-Bertrand Aristide. Aristide unlike Duvalier was a Catholic priest before relinquishing his priesthood for presidency. As compared to Duvalier, Aristide did not have the great impact on the religion in the manner of his predecessor, but similar to 
Duvalier he condoned Vodou. Aristide realized that discriminating against any particular group would hinder his campaign. During his rise towards presidency, Aristide invited all Haitians regardless of faith to participate in his campaign and elected him into office. Promising radical reforms, the poor greeted him as a messiah and a means by which they would be able to receive economic growth and equality. After being elected into office, Aristide called a meeting with all religious leaders of the country including Ougan priests to plan strategies for the overall growth of the nation. Vodou practitioners for the first time saw their fate reaching credible heights that was not previously held for them. They now were involved in the democratic rebuilding of a nation. They are no longer needed to abide themselves to secret locations or lie about their religious preference. In the eyes of many Vodou practitioners, Vodou finally reached the status that was long denied in the religious sector of society. "Perhaps one of the most significant changes in the church recently has been its unofficial recognition of Vodou as a significant element in the Haitian culture" (Desmangles 1992: 57); as a result of the church's recognition of Vodou many followers convert to Protestantism.

In the year 2003, President Jean Bertrand Aristide declared Vodou aside from Catholicism religion of the State. Now, Vodou is a religion that could be practiced and adored by the masses of every socio-economic standing without any fear. In 2011, President Joseph Michel Martelly granted a reputable place to the Vodou religion and its practitioners after he ordered a state funeral in honor of Enord Fortuné also known as Azor singer and drummer of "Rasin Mapou." ${ }^{\text {"38 }}$ The ceremony was held in Champs de

\footnotetext{
${ }^{38}$ Haitian folkloric group, specialized in folkloric music that includes Vodou traditions and ceremony
} 
Mars $^{39}$ under a perystile ${ }^{40}$ prepared for his final farewell. Max Beauvoir head Vodou priest presided over the ceremony which was broadcast live all over the country and in the diaspora (Pierre Louis 2011). Following the Duvalier regime, Arisitide and Martelly recognized the fundamentals and the importance of acknowledging ancestral traditions a prerequisite in successfully taking political control of the nation.

\footnotetext{
${ }^{39}$ A popular Boulevard in Port-Au-Prince Haiti

${ }^{40}$ Vodou temple
} 


\section{Chapter five}

\section{Results and Discussion}

\section{Statistical Analysis}

The literature explains that causes of conversion vary, depending on the society in

question. In order to analyze conversion, religion must be taken or explained in a societal and cultural context. Causes may be valid in one society and not valid in another, it all depends on the society's needs. Since religion answers to deep human needs, when one religion fails to provide answers or meaning, people convert or move from one religion to another where they feel like they might find answers. To understand conversion and to put some meaning into religion, the sociological aspect must be studied. Therefore, to have a better understanding of conversion in Haiti, the conditions and characteristics of human life in Haïti must be analyzed.

To analyze the causal conditions, survey interviews were conducted with data collected searching for differences in similarities in the causes of conversion, and role that Vodou plays after conversion in Haiti and in the Haitian community in Miami. According to Horton's theory on conversion "As the social relationship and the boundaries are redefined due to social change, less attention is paid to lesser spirits, and the supreme being takes over as an important reality which helps them (the converts) to understand, predict and control events." (Oommen 92). To analyze the causes of conversion disappointment with the church, the variable will be measured according to whether or not the church fails to address the social and psychological needs of followers. Economic condition will be measured according to convert's economic condition prior to 
conversion. According to the literature, conversion is not usually an inner decision, it is also important to figure benefits perceived by alleged converts.

A young woman in Jeanty, a small town in Haïti, said usually people who cannot do anything to better themselves become Protestants. Since conversion, is anticipated by internal and external forces, community/environment Protestant encounter plays a major role in the analysis. It explains factors involved that may trigger conversion: an event, missionaries, and the services provided in the community, or family member. Religious affiliation is important when seeking certain positions in Haït. In the Baptist Hospital in Jeanty, according to people in the community, people affiliated with the church received better treatment.

In illness and healing lie the controversies of religious conversion in Haïti. According to the literature many converts believe the only way to cure Satanic Illness (illness sent by enemies) is by resorting to magic. However, conversion to Protestantism means rejection of Vodou and all of its practice. The variable is analyzed according to the awareness of convert regarding an illness of Satan. The awareness is based on the effectiveness of biomedicine; once medicine, and prayers fail, the question remains would convert, consider turning to Vodou for cure?

For bias purposes data was collected from converts, lifelong Catholics and Protestants. While collecting the data, many converts expressed that Catholicism and Vodou viewed compatible however, not all catholics serve the spirits. In addition, it is absurd to predict that because one has converted from one religion to the other, when ill they are more likely to revert to Vodou, it is even more absurd to assume that lifelong Protestant never turn to vodou. The data analysis for this research was gathered through 
survey interviews with church followers, books, journals, and interviews with church elites. Two statistical procedures were used to analyze the data: Frequency distribution and analysis looking for variance in factors that can explain conversion.

\section{Leading Cause of Conversion}

In analyzing the causes of conversion in Haiti, the choice pattern that led to conversion from Catholicism to Protestantism was established. In my study four causes were selected, disappointment with the Catholic Church; economic condition of alleged converts; community/ environment; illness/near-death experiences. My study proposes ethnographic answers to the frequency of the choices made by people to convert from Catholicism to Protestantism. Disappointment with the Catholic Church was the most popular cause. According to a convert, some people want to get more involve in church activities, they are searching for a sense of community building which influenced their conversion. Many criticized the Catholic Church for being too liberal with its followers; they are able to assist a Vodou ceremony and continue attending mass every Sunday. While many converts have their personal interest when converting to Protestantism, it is expressed in the ethnographic answers that there is a longing for community empowerment and structure in the society.

The data was gathered from a variety of sources; interviewing church leaders, priests and pastors, converts, lifelong Catholics and Protestants. On the basis of the literature one may hypothesize that the deeper one's poverty, the more likely he/she is to convert to Protestantism. People who live in a predominantly Protestant community and whose family, or friends belong to Protestant churches are more likely to convert than people who do not share those characteristics. The relationship between one of the 
independent variable, disappointment with the Catholic Church and the dependent variable conversion from Catholicism to Protestantism in Haiti is statistically significant. Regardless of educational background and gender 100 converts were interviewed in Haiti. Most of the interviewees were between the ages of 18 to 44 .

Figure: 8

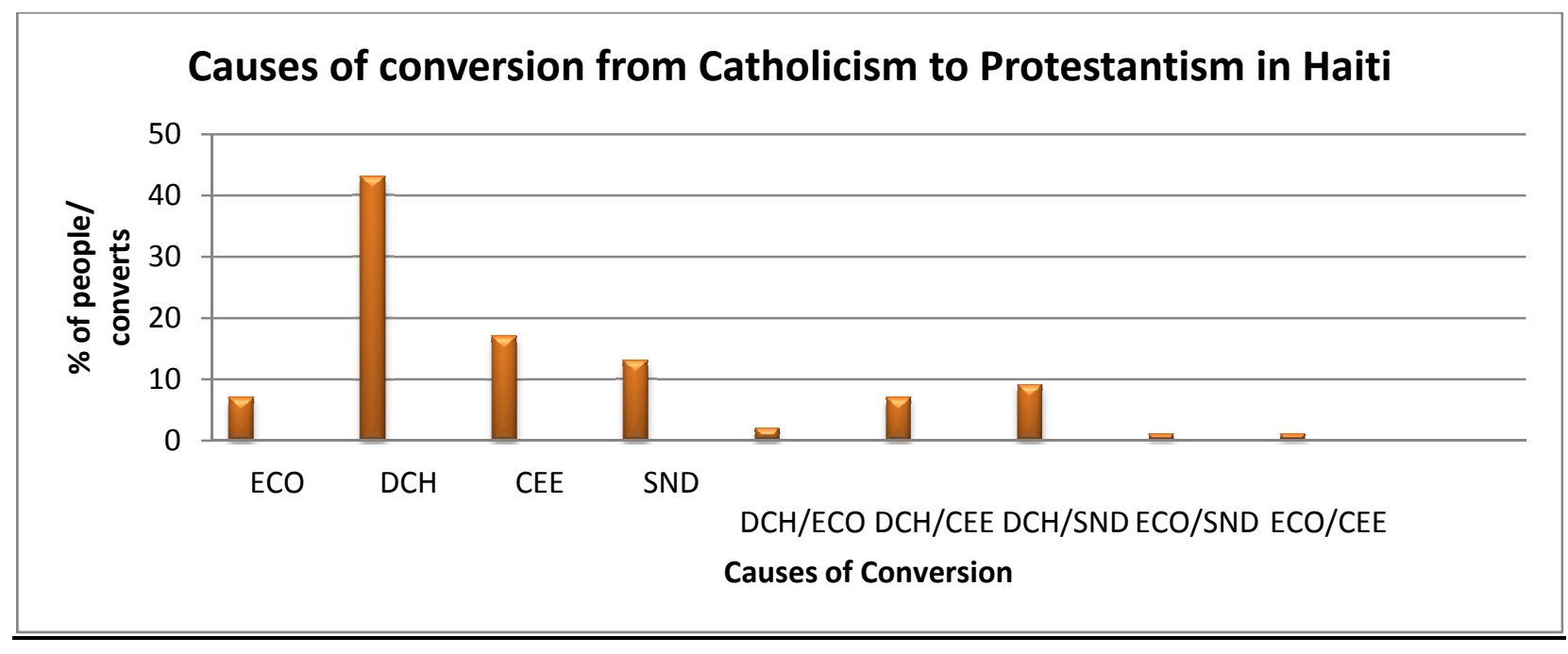

Many people with a formal education, high school graduate or higher filled out the questionnaire and included their perspective on religious conversion and the role of Vodou in Haitian society. Others answered their questions orally; out of 100 people $0.43 \%$ shared that their conversion from Catholicism to Protestantism was the result of their disappointment with the Catholic Church; $0.07 \%$ selected economic reasons, $0.17 \%$ their environment friends, family members influenced their conversion, $0.13 \%$ were either sick or had a near death experience. Some interviewees did not select a single cause, $0.09 \%$ of them admitted it was a near death experience combined with the disappointment of the Catholic Church, $0.07 \%$ of them said it was a combination of their environment and disappointment with the Catholic Church, $0.02 \%$ people selected 
economic and disappointment with the Catholic Church, $0.01 \%$ move from one religion to another was caused by economic and illness and $0.01 \%$ person selected economic and environment/encounter.

The data collected did not completely support the hypotheses that the deeper one's poverty, the more likely he/she is to convert to Protestantism. People who live in a predominantly Protestant community and whose family, or friends belong to Protestant churches are more likely to convert than people who do not share those characteristics. Though the survey answers demonstrated that converts' disappointment with the Catholic is their main cause or reason for conversion; however, illness near death experience and environment/Protestant encounter plays a major role in religious conversion in Haiti. Since Catholicism and Vodou co-existence and based on the result of the leading cause of conversion in Haiti; one may insinuate that the disappointment with the Catholic Church may also refer to a disappointment with the Vodou religion. "It is theoretically possible even predicted according to the Gerlach and Hine's model that individuals with high needs for affective ties and possible other basic needs such as food and shelter convert to a group which they had no basic congruence" (Richardson and Stewart p. 39). The quote creates and enlightened the understanding of the choice made by converts from Catholicism to Protestantism. In an interview, one of the converts admitted how she feels wanted and enjoys being Protestant, "If my child is not feeling well and I missed a meeting or a service, a group of people will come to visit my child; when I was in the Catholic Church it was not like that." While many people convert in search of a more inviting and warm environment some Catholics remain faithful to their Church. 
The sample taken in Miami confirmed the forces of the Vodou religion across the waters and further accentuates its effect on Haitian identity. Twenty three percent (23\%) of converts expressed that they have never return to Vodou since their conversion to Protestantism, 36\% lifelong Catholics do not serve Vodou spirits, however they worship the Saints in the Catholic Church; $25 \%$ of Catholics and converts admit to visit or took part in a Vodou ritual; $10 \%$ with no denomination but will attend any church and $6 \%$ admit to going to church on special occasions. The data shows cultural traditions crossing the Atlantic similar to how Vodou arrived in Haiti and have embedded its roots in Haiti society.

Why do some Protestant converts revert to Vodou when they are supposed to reject Vodou? Forces of Vodou would not have been deeply rooted in Haitian life, without the satisfactory of the adepts (Fontus 2001). Vodou contributes to the social and communal life, which unifies family members under the concept of lakou. ${ }^{41}$ It is the organization of a social and economic system under the supervision of a leader. Children with the same father upon reaching adulthood receive land to cultivate or to build their homes in the lakou with the help of family members. Communal living provides relaxation for the hard working peasants, hope, protection and relief from oppression, injustice, insecurity, and discrimination. It helps developed artistic talents, knowledge of traditional medicine available for all, influence respect for nature. Until today, you can hear certain conversation amongst Haitians especially if having economic hardship, or feeling like things are not going their way; they will refer or mention the desire to visit their lakou even if they live outside of Haiti.

${ }^{41}$ Living in a tribal community 
Considering the sense of community empowerment under which evolves the introduction of Vodou in Haiti during the colonial era, the country today is divided. Since Vodou plays a major part in Haiti's history it is also a major factor that contributed to Haitian identity. Lack of understanding, misleading literature on Vodou accompanied by a multiplicity of factors has turned Haitians against each other. "National identity or self is born in the congruence between the beliefs of a community and those of the state (Premdas 1998: 9). In Haiti the state's belief differs from the community's belief. While it is widely known around the world that a large number of Haitians in Haiti and abroad practice Vodou; the official religion of Haiti is Roman Catholicism. Previous census taken in Haiti has always captured Catholicism as the most practiced religion in the country due to syncretism and there is an inference that many Catholics practice Vodou. Even after the decree in 2003 that legalized Vodou many are still skeptical about the public integration. According to father Claret,

"The decree is more political than anything, people were always free to participate in Vodou ceremonies before the decree; the ones who go out at night will continue to do so because that's what they find mysterious in the religion. The only difference is now a marriage performed by an Ougan priest will be recognized by the state. I do not know if the decree will make an impact in a couple of years"

"Vodou is something that has always been behind closed doors, or considered as something from andeyo ${ }^{42, " ~(c o u n t r y s i d e) ~ s a i d ~ p a s t o r ~ P h i l l i p p e ; ~ h o w e v e r ~ s o m e ~ p e o p l e ~}$ believed that the decree is a good move they can finally see "the real Vodouisant." Regardless of Vodou's position in Haitian society,

"All Haitians have Vodou in their soul, they may not practice religiously but there are certain aspects of Vodou in the Haitian culture that all Haitians have and maintained." (Jean-Marie Reginald 2004).

${ }^{42}$ Areas outside of the cities 
Pastor Phillipe also added that "all Haitians have Vodou in their blood, but they are not at all Vodouisant. For example men after urinating would spit, in the Vodou language you do it so the devil won't take your soul but as Protestants we do it because Vodou is our roots not because we are Vodou practitioners. Fear and certain behaviors sometimes give us Vodou's characteristic; Vodou is a strong determinant in our culture. People have to understand that Vodou is not 'the Haitian culture' it is an aspect of it."

There are various types of religious changes and different kinds of conversion. However, in all of these kinds of conversion evolved identity crisis (Massino 2004). Conversion or learning new religious ideas, destabilization of self implies a loss of personal identity (Massino 2004). In Haiti this loss of identity implies controversy within the religious conversion. Converts constantly switch back and forth from one religion to another searching for meaning and purpose. Father Claret said that "the presence of the Catholic Church in the community is to evangelize the people without colonizing the Haitian culture." However, "when the Catholic church realized they were losing followers because the praising style was not successful, the church begin to create a system similar to Protestantism such as singing similar song, organizing jèn( prayer sessions) regularly to attract more people” ( Phillipe Frantz 2003). According to Massino the group or community to who converted people belonged or still belongs to does not know how to integrate them. Instead of developing strategies rooted in the culture to evangelize the followers, religion in Haiti can be seen as a tug of war. Since the controversy of conversion in Haiti lies in illness and physical condition and the practice of Vodou after conversion; Vodou in Haiti fails to rationally integrate and organized its followers. Many are functioning with a sense of instability and loss of identity. According to Pastor Phillipe, 
The 2003 decree that legalized Vodou will affect the society in a positive and negative manner. On the negative side many will profit the situation. On the positive side, we have never seeing a school or a hospital built by vodouisant, now since they have freedom we need to see what they are going to contribute in the development of the country."

Even across the waters Haitians have maintained their culture. According to father Reginald,

"A lot of people come to Miami illiterate, which makes it more difficult to receive employment. Their superstitions led them to believe in 'bad luck' instead of going to school they pray all day and all night for a job. And when they do not receive one, they lose faith" (Jean-Marie 2004)

Some of them turn to the spirits, call back home for family members to investigate by consulting an Ougan on their behalf or take a beny chans(lucky bath) very discreetly in hoping to remove 'evil spirits' surrounding them. Within the Haitian community in the Diaspora there is a new movement surfacing amongst Haitians. According to Louis,

"Within a transnational social field, Haitian Protestants use churches and organizations to shape the identities of present and future generations of Haitian ns according to Protestantism furthermore, while conducting ethnographic research Karacte ${ }^{43}$ came up repeatedly as an issue of focus essential to the ultimate goal of the transformation of Haiti into a Protestant Christian nation and, by extension of the catalytic effect of Protestant Christianity on Haitian society, a viable nation-state" (Louis 2010:13).

In interviewing Protestant converts in Miami Florida, many people converted to Protestantism, because they love the ambiance. Many of them feel like if vodou could really do something, Haiti would be better off than it is right now; Vodou will help for a price, and if you do not accomplish your promise evil things will happen to you; some converts without faith or confused spiritual beliefs continue to practice Vodou after conversion. Others also admit that in general people who criticized Vodou do not know

${ }^{43}$ Character 
anything about Vodou; it is an aspect of the Haitian culture. They even agreed to follow the Protestant ideology; however they want to be involved in a setting where they can still feel at "home." According to Butler, music in the church celebrates their identity. By infusing religious music with the Konpa ${ }^{44}$ style (Butler 2002: 78) will keep people in the church and away from $\operatorname{lemonn}^{45}$; though they are careful not to include the drum in order for them to maintain their distance from lemon or another word Vodou (Butler 78).

In supporting Norris's idea on cultural beliefs and practice,

"The modern musical activities of many Haitian churches are deemed inauthentic or artificial to the extent that they rely on emotionalism and entertainment rather than on the Holy Spirit for affective impact. The preachers leading people to raise their hand dance not to stay quiet... if not you are refusing to praise God" (Butler 82).

People should not be subjected or pressured when making a religious change. "A voluntary convert is adopting beliefs interpreted through an already existing system. Adherence to ritual requirements must come from personal meaning, not authority" (Norris 2003: 172). Christian theology in Haitian society describe the house of God as a peaceful place, spiritual tranquility, all a person has to do is follow the 10 commandments and pay $\mathrm{dim}^{46}$ then you will have a rewarding afterlife. As many scholars have argued for centuries, "Conversion to Christianity is a complex multifaceted process involving personal, cultural, social and religious dimensions" (Mendoza 2003: 205). On the basis of the literature on conversion in Haiti it is not prejudice to assume that Protestants

\footnotetext{
${ }^{44}$ In Haiti seen as emblematic of the respective nation-states

${ }^{45}$ Wordly activities (Catholics and Vodou)

${ }^{46}$ Thites
} 
converts are more likely to turn to Vodou when they are sick than people who are lifelong Protestant.

"Some converts or lifelong they may not go personally to see an Ougan they send someone else or they go in secrecy. You hear the expression L'agno pa jan-m bliye chemin- $l^{47}$; some pastors visit Ougans all the time for personal reasons, Christians do not. Some pastors even have magic on the altar, some do it for promotion, money, or to have a lot of followers."(Phillipe Frantz 2004).

For the conversion process to be successful in Haiti it needs to be rooted in the religious tradition and the culture of the country. According to Louis, "Haitians, who are raised as Protestants and Haitians who convert and remain Protestant, form a collective voice that critiques the problems of Haiti and Haitians as spiritual and Cultural" (Louis 2010:13). Since Vodou is embedded in Haitian identity, it should not be viewed as "the enemy." Pentecostal has found a successful niche in the Caribbean as a consequence of their style of worshipping and their emphasis on healing, trance or spirit possession, dancing, and singing that are similar to African traditions. Around previous beliefs new beliefs should be organized in order for continuous success of the conversion process. According to Norris "a convert does not take on merely a new set of beliefs but rather a new set of beliefs as understood through the old one." In Haiti, converts take on their new beliefs as understood through the old one Vodou, which leads to the conclusion that Protestant converts revert to Vodou when they are supposed to reject it. According to pastor Phillipe,

"In Pentecostalism Haitians exalt as if they were in Vodou because they have a vibrant soul, they are alive. The church attracts more people because they find themselves in the ambiance that they like. We have to remember and understand that before conversion Haitians danced carnival, assist Vodou ceremonies but now it is not done in that manner anymore; it is done in a way where the same rhythm is playing with different words."

\footnotetext{
${ }^{47}$ The lamb never forgets its path
} 
Causes of conversion differ depending on the society in question. In Haiti disappointment with the Catholic Church is the leading Cause of conversion; however the other causes delineate religious change in Haitian society and the practice of Vodou in Haiti after conversion reinforces the status of cultural beliefs and traditions in the society.

Often, in healing practice surfaced the confusion during the conversion process. A large number of people will consult a spiritual leader for advice before a health professional. When evangelizing the Haitian people, missionaries have to take into consideration that "Beaucoup d'Haïtiens sont étrangers, exclus chez eux ${ }^{48 \text { ", }}$ (Nerestant 1994) for that matter; sensibility to their culture becomes a crucial aspect in their evangelization. The success of the process relies on whether or not converts follow the new ideology.

"Given that cultural beliefs and practice shape experience and that the meaning of religious language and ritual is grounded in embodied experience converts initially understand the symbolism and language of their adopted religion through the filter of their original language and worldview. This applies not only to ideas but also gesture, posture and ritual, furthermore any term used in the adopted tradition, such as love or prayer, can only be understood by the convert through already existing internal definitions " (Norris 2003: 179).

In considering Norris's idea, evangelization of the adepts should "acknowledge medical diversity that exist in Haiti avoid making people choose between biomedicine and traditional healing and working collaborate with family and community spiritual leaders ${ }^{49}$ " may lead to a successful conversion. Beauvoir's comment supports Norris's idea on cultural beliefs and practice, "Vodou is seen, and practiced from different point of

\footnotetext{
${ }^{48}$ Many Haitians are foreigners excluded from their homeland.

${ }^{49}$ Southern National Reference Tuberculosis Center
} 
views. But when I look at the Haitian population, I say that it is a Vodouisant population. That's how the whole world sees us, once you say Haiti you say Vodou and vice versa, meaning there are certain characteristics on the land of Haiti that Haitians do that make the world believe Haitians are Vodouisant." In understanding Norris and Beauvoir one can agree with scholars such as Mintz, Trouillot and many more who have been affirming for centuries that Haiti is $100 \%$ Vodou. During my field observations, on religious conversion in Haiti I have made reference to the Ellison Model in an attempt to understand the society and in an effort to explain religious conversion from a societal point of view. The Ellison Model in many ways reflects the dilemma of the Haitian society and explains the effect of religion on the society.

\section{The Repercussion of Religion on Haitian Society}

After conducted my research on religious conversion in Haiti and the role of Vodou after conversion, I use the Ellison model to explain the repercussion of religion on the Haitian society. The Model shows three different models on community building. Out of conversion in searching for meaning and a need to belong surfaced the fragmentation of Haitian society supported by evangelization. It will be used to represent the dominant religions and their effect on Haitian society. The first model is Building the inclusive community representing the Haitian society. The second model will elaborate on building the Discommunity, religion in Haiti and building the inclusive community while taking into account the Discommunity, definition, Motivations, and Values of each, Vodou in Haitian society. 
Figure 9: Inclusive community signaled by clockwise movement towards systemic values.

\section{BUILDING THE INCLUSIVE COMMUNITY}

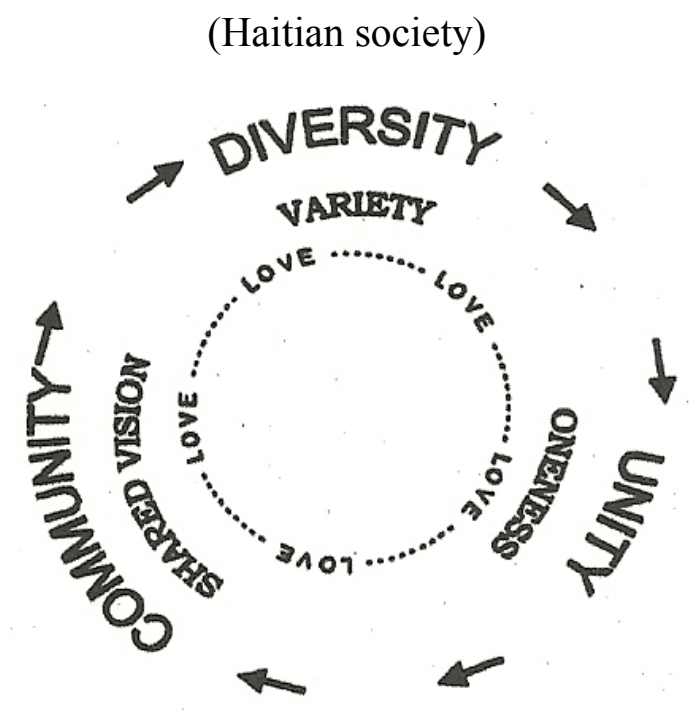

"The three procedural steps for building community are encapsulated in the movement: 1) from diversity 2) to unity 3 ) to community. Diversity (or division) is detected from people being in a state of conflict... during this stage of "discommunity." "There are opposing factors at work, ushering in displacement and lack of togetherness, stability and love to isolate and destroy." These parties must learn to quell their prejudices and join forces with others in order to accomplish the goal of community. Their values allow disrespect, dishonor and fear to guide their relationship with others." (Rice, 21)

The particular movement of the model building the inclusive community from diversity to unity and to community is a direct reflection of Haitian society. There is a dire need for community building within the Haitian society; however, the focus has always been on a specific governing group. The country's instability and economic crisis have placed the burden on the country's leaders or Vodou. Many fail to realize the opposing factors, the forces in place ensuring lack of togetherness enabling the people to unite on common ground. Throughout my field study in Haiti, it can be seen within the structure of the society how last names or titles give certain people leverage to dehumanize others, the ability to communicate in the French language also give people power over others. In 
addition, the barriers supported by fear credited to Vodou imposed on the success of community building. Many people convert to Protestantism "because they find a sense of community building." (Father Reginald).

Figure 10: Operation of discommunity illustrated by the counterclockwise movement of discommunity systemic values.

\section{BUILDING THE DISCOMMUNITY}

(Religions in Haiti)

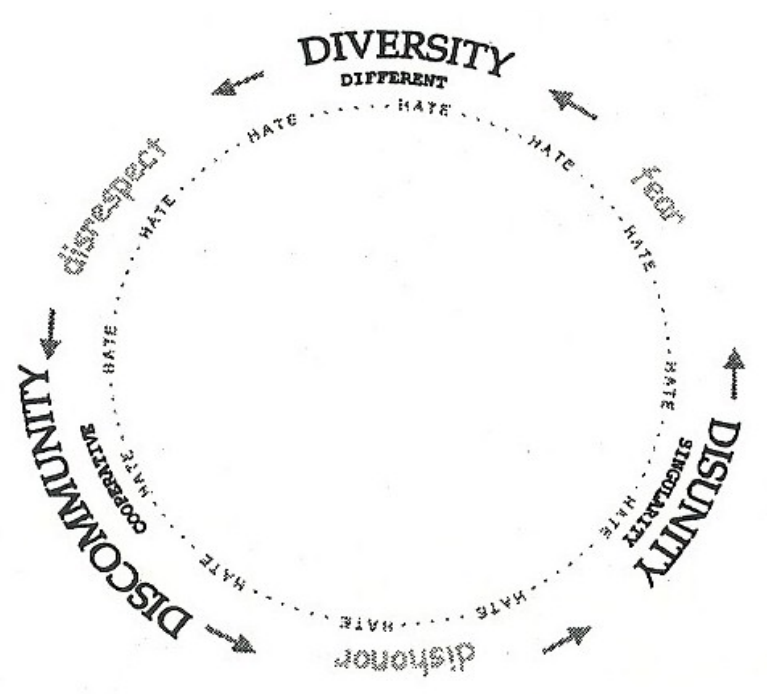

"In this model of discommunity, diversity is divisive. For instance, people are not seen as positively contributing to the variety that is found in society. Instead, people who do not belong to a particular group are viewed in a negative light, as different, as weak or as outcasts. The unity the group espouses is not viewed in terms of harmonious reflections of the whole group. Instead, it is a unity born out of individualistic sense of superiority, and it thrives in people with like-minded perceptions." (Rice 22)

Different religions in Haiti are represented in this model. The function of the different denomination is portrayed in the diversity, disrespect, dishonor, disunity and fear. The model represents religion in Haitian society to the core. According to Louis many Haitians Protestants believe" the practice of Vodou since the Bwa Kayiman ceremony is the main reason why Haiti is mired in a socioeconomic crisis." Protestants in Haiti and in 
the Diasporas believe that conversion to Protestantism is a remedy that can transform the poorest nation in the Western Hemisphere into a viable nation-state (Louis 2010:1). The ceremony and the sermon that have placed Haiti as the first independent black nation at a time when slavery was at its peak is seen as the beginning of Haiti's calamity.

Protestants refer to the Bwa Kayiman as a "Vodou congress, as a moment where Haitians procured their freedom from colonial powers through consecration with $d y a b^{50}$ (Louis 2010: 4). While history glorifies the ceremony as the motivational sermon that lead to the Haitian revolution, "many Haitian Protestants find Bwa Kayiman offensive" (Louis 2010: 6).

Vodou though culturally acknowledged by many Protestants is still marginalized "a group called "Vision: Haiti" marched on August $14^{\text {th }}, 1998$ to Bwa Kayiman with the intent to exorcise Vodou spirits to "win Bois Caiman for Jesus" by performing a Jericho march...commanding its walls to fall down. By undoing that contract and claiming the birthplace of the Haitian nation for Jesus, however, the pastor had symbolically "won Haiti for Jesus" and converted the entire nation to evangelicalism (Louis 2010: 8).

The event was not only insulting to Haitian nationalism but also threatens the identity of the posterity. "Many Protestants admit that Vodou is part of Haitian culture and that it is part of their rasin. $^{51}$ But Protestantism as Romain (1986) explained is a religion of rupture. The rupture occurs with lemonn ${ }^{52}$ and the rejection of Vodou is essential to becoming kretyen $^{53}$ (Louis 2010:7). The ruptured mentality divided the country in a way that community building is viewed as virtually impossible. The number of Protestants is not only increasing in Haiti but also in the Diaspora. In a survey conducted in the

\footnotetext{
${ }^{50}$ The devil, satan

${ }^{51}$ Roots

${ }^{52}$ The secular world

${ }^{53}$ Christian
} 
Bahamas, when responding to survey questions concerning the religion they currently

practiced, $27.7 \%$ of the interviewees responded "Catholic" whereas $29.1 \%$ percent

replied "Anglican" Baptist or Pentecostal (Louis 2010:2). Religious discrimination

within the Haitian society one of the major issues obstructing community building and

religions in Haiti greatly supports the societal rupture. According to father Reginald,

"Vodouisants need to be respected if in the past there were errors, or pressure but today we have to move on to the present we have to understand the people and put them to face their freedom. The ones who have chosen Christianity have to be respected just like the ones who have chosen Vodou. It is their choice and we have to respect it while continuing to preach the word of God. It is up to the person to choose the word and make the first step the Catholic Church does not give pressure and Catholic followers should not allow themselves to be pressured by the Protestants or the Vodouisants."

Figure 11: Illustration of the opposing operation of two systems, community and discommunity, driven by opposing systemic values.

\section{BUILDING THE INCLUSIVE COMMUNITY}

The Discommunity, definition, Motivations, and Values of each

(Vodou in Haiti)

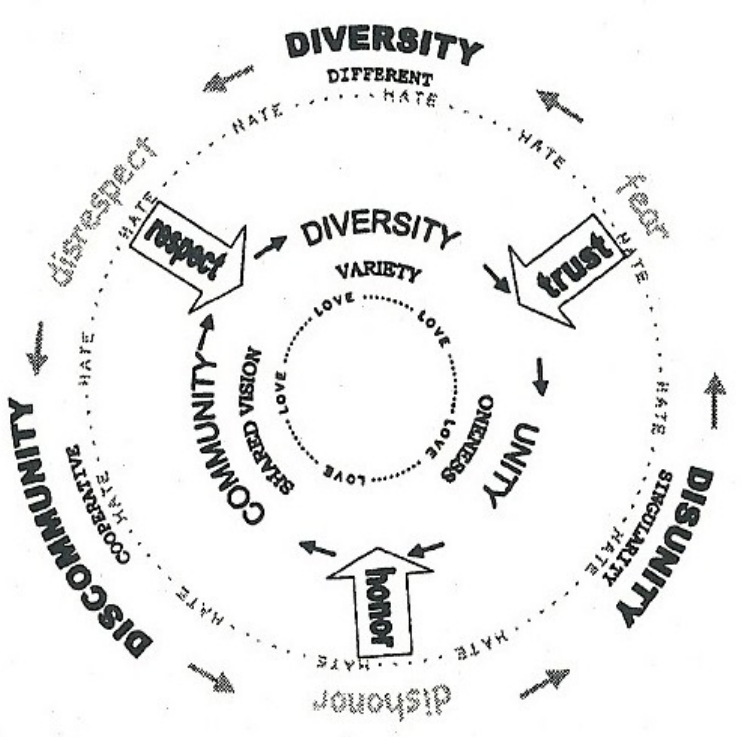


"The community found in discommunity is not perceived as a fellowship of people who share a universal concept of human brotherhood and sisterhood, or who have a genuine fondness for one another and espouse common goals that are inclusive in nature. Instead, the community in a state of discommunity is much more of a cooperative, whose goal is to advance only the social and economic welfare of those belongings to the group. They may share the same race, ancestry or belief system. Ultimately, hate is the central value esteemed by builders, while the value esteemed by true community builders is love" (Rice 23).

The model demonstrates in many ways the outlook of the Haitian society and the world toward Vodou. The model combines the previous two models and includes the community found in discommunity linked by respect, honor and trust. Vodou has never given the respect that it deserves even after its implementation in Haitian identity. It is viewed as the religion of the peasant, poor and the cause of Haiti's misfortune. Although Vodou may not have strategies in place to recruit in large numbers there are many followers publicly and in secrecy. The division of the Haitian society as either rich or poor categorized Vodou as the religion of the impoverished. However, it is biased to imply that Vodou is not practiced by the elite.

According to Berger, "one of the fascinations of a large city is the immense variety of human activities taking place behind the seemingly anonymous and endlessly undifferentiated rows of houses. A person who lives in such a city will time and again experience surprise or even shock as he discovers the strange pursuits that some men engage in quite unobtrusively in houses that, from the outside, look like all the others on a certain street. One will repeatedly find oneself wondering what may be going on...perhaps a strange cult...The façade of the houses cannot tell us...The social mysteries lie behind the facades. The wish to penetrate to these mysteries is an analogon to sociological curiosity" (Berger1963:310).

The quote describes the large cities in Haiti, more specifically the capital Port-Au-Prince known as "residence of the Haitian elite" where the untraceable rumbling sound of different rhythm of drums behind 12 feet walls make one wonders the social mysteries lie behind the facades. Within that circle the members support, respect, and love each other. 
From others' viewpoint Vodou has no power to promote love, respect and community building. Protestants trivialized Vodou, as implied by Pastor Lesly "Haitian power structures and institutions and any other forces responsible in shaping the character of Haitian citizens have failed and Protestant Christianity is the only force that can built character of each individual Haitian" (Louis 2010: 16). Pastor Lesly failed to take into account that,

"Theology constitutes part of the DNA of the conversion process for people existing within a particular religious tradition. Not all conversion are seen in the same way because theology that informs the psyche and culture of the person going through conversion is deeply embedded in the structures that serve as foundation, infrastructure, and motivation of the conversion experience" (Rambo 2003: 315).

In Haiti for many it seems as if Vodou does not exist. The rejection of the religion practiced by the masses has established a sense of struggle within the society. Vodou does not discriminate or belittle other religions; however people have to be knowledgeable of the religion in order to become true followers because Vodou has no known strategies or an organized hierarchy in place to persuade people.

\section{Conclusion and Recommendations}

The perplexity of religious conversion in Haiti portrayed religions in the country in a struggle to conquer souls. The literature explains that causes of conversion may vary, depending on the society's needs. Since religion answers to deep human needs, when one religion fails to provide answers or meaning, people convert or move from one religion to another hoping to find answers. Therefore, understanding religious conversion in Haiti is complex because of the characteristics and conditions of human life in the country. Four causes of religious conversion in Haiti were analyzed; 
disappointment with the Catholic Church according to the study is the leading cause of conversion, as stated by Father Claret "In the Catholic Church, people come to church and leave sometimes without exchanging words with one another unless they are members of the same group" amongst other reasons mentioned in the study people are yearning for affective ties. Any religious ideology able and willing to meet and fulfill their needs will encourage their receptiveness; however, this fulfillness is relevant during the initial commitment to the conversion process (Mendoza 2003). As people acquire knowledge in the adopted religion they may rediscover the tradition they left behind (Lamb and Bryant 1999). The hypothesis that people who live in a predominantly Protestant community or have high amounts of Protestant encounters are more likely to convert is significant to the study. As confirm Coleman, conversion under the right conditions can help sustain a religious life (Coleman 2003).

During the interview with Pastor Phillipe in discussing whether or not Protestant converts or lifelong Protestants revert to Vodou in addition to the circumstances mentioned in the study, he also added that the practice of Vodou after conversion depends on the person's relationship with God because he cannot really say whether or not the conversion is true. In addition, conversion is a process in which a person has to continue to better him or herself everyday in order to be a role model in the community (Leon Claret 2004). In taking into account the role of religion in Haitian society; religion in Haiti has failed. Religion in Haiti has not taken advantage of its influence over the people. The influence should have been used collectively as a long term project in the development of the country. Instead, religion has fragmented the Haitian society even further apart. 
Changing one's religion in Haiti is impenetrable due to Vodou, the religion practiced by the masses in Haiti, deeply rooted in the Haitian cultural traditions (Rambo 2003). Religious conversion in Haiti is supported by Bordieus's theory on religious habitus and Mendoza's theory that religion is understood through social and cultural traditions. Vodou African traditional religion allowed Haitians to practice other religions. Vodou in Haiti according to the literature is embedded in Haitian identity. therefore, many Haitians may not practice Vodou, it may be portrayed in Haiti and around the world in a negative light, however, "religious emotions and worship experiences are learned through association and enculturation" (Norris 2003: 177). As we analyzed the literature and the interviews, all Haitians may not practice Vodou; but there are certain characteristics in the society that are inherent to Haitians that make the world believe Haitians are Vodouisant (Beauvoir 2004).

Even after scholars have enlighten the world on religion, politics and economy in Haiti; until today, in the $21^{\text {st }}$ century many believed Vodou is the culprit preventing Haiti from walking the road of development. If the Vodou religion had an organized hierarchy "his story" (history) would certainly not give Haiti any credit. The forces of Vodou remain evident even in developed societies where spirits are not as revered for example the United States.

Other religions in the country need to work together with Vodou practitioners in order to understand the dynamics forces of religious conversion in Haiti. Religions in Haiti should promote community building by joining forces with Vodou in order to help the developmental and sustain the democratic process in the country; because many converts will continue to practice Vodou together with Protestantism. Instead of constant 
demonization of Vodou, the religion practiced by the masses; other religions in the country need to understand that Vodou does not only serve as an intermediary between the different religions in the country, it dominates religious conversion in Haitian society and contradicts conversion in Haitian life.

If Vodou is blamed for Haiti' misfortune then religions in Haiti overall should share the blame, because like Vodou they have also influenced the society positively and negatively. Under development in Haiti is not a result of the practice of Vodou; neither the absence of the church for more than one decade, nor the different religions currently present in the society. It is however, the result of the following:

Massive migration local and international, infrastructure, fear, insecurity, constant exploitation local and international, increasing rate of poverty, illiteracy, massive unemployment, limitations impose by force and fear, result of economic crisis due to recognition as an independent nation, rural code of 1826 that reintroduced slavery and excluded the peasantry in political development of the country, children subjected to lifelong servitude (restavèk) the idea of work associated with slavery, religious institutions serving the power local and international, rigid division of the country into social classes, the concentration of power on one sector of the society, imposed democracy, the notion of skin pigmentation, the usage of the French language as a tool of power used by political leader to condone the division in the society simply to benefit their claim of absolute power, borrowing money from the French to pay the French for recognition of the country's independence, fear of a French invasion that have paralyzed the country's social and economic development, the presence of a Black Republic in an era where many countries economy relied on the black slaves, the inhuman conditions of 
the Africans slaves that have never been addressed and that have passed down from generation to generation and more.

In a society that remains segregated due to social class division and injustice, religions should not remain silent it should denounce social injustice and serve as a voice for the people. Religions in Haiti must educate the masses; it must promote community building in order to save lives. Out of ignorance and fear of Vodou people lose their life on a daily basis while religions in Haiti compete for souls. There is an educational need local and international on Vodou. Missionaries and others providing services to Haiti should acknowledge medical diversity in the country especially since many people will confide in a spiritual leader before visiting a doctor. People should not be condemned for making such a choice; however leaders (Ougans and doctors) should work in a consensus in order to help people identify problems or illnesses that require medical attention especially in the rural areas where resources are limited.

According to Merrill, foreign affairs suppression of Vodou conceived foreign policies such as the Code Noir in Paris, the Vatican, in Washington during U.S. Marine Occupation and most recently the United Nations all provoke internal friction and social division. Religious conversion in Haiti may be seen as a survival strategy for many; however evangelization leading to conversion can be interpreted as a creative form of resistance and even subversion to the Vodou religion (Rambo 2003). Despite all efforts made to smother Vodou, it remains the religion practiced by many Haitians in Haiti and the Diaspora even after conversion to Protestantism. ${ }^{54}$

\footnotetext{
${ }^{54}$ WorldFact book
} 


\section{LIST OF REFERENCES}

Anthony Dick and Thomas Robbins. (2004). Conversion and "Brainwashing" in new Religious Movements. In I. James Lewis R. (Ed.), The Oxford Handbook of New Religious Movements (pp. 243-297). New York, NY: Oxford University Press, Inc.

Assellin, C. (2002). Haitian exceptionalism and Caribbean consciousness. Journal of Caribbean Literatures, 3(2), 115-130. Retrieved from http://www.jstor.org/stable/40986134

Berger Peter, L. (1963). Invitation to sociology: A humanistic perspective. Garden city, New York: Anchor Books edition.

Beauvoir M. (2004, December 17). Interview by Y. Menard-Saint Clair [Personal Interview]. Causes of conversion from Catholicism to Protestantism in Haiti and the role of Vodou after conversion.

Brodwin Paul. (1996). Medicine and morality in Haiti: The contest for healing power. New York, NY: Cambridge University Press, Inc.

Brown McCarthy Karen. (1987). The Encyclopedia of Religion, 15, 296-301.

Butler Melvin, L. (2008).Dancing around dancehall: Pentecostalism, popular culture and musical practice in transnational Jamaica and Haiti. In I. Holger Henke, I. Magister Karl-Heinz \& I. Trotz Alissa (Eds.), Constructing vernacular culture in trans-Caribbean (pp. 63-93). Landham, Maryland: Lexington books.

Butler Melvin, L. (2002). Nou kwe nan sentespri (we believe in the Holy Spirit: Music, ecstasy, and identity in Haitian Pentecostal worship. Black music research, 22(1), 85-125.

Retrieved from http://www.jostor.org/stable/151996

Cnaan, R., Boddie, S., \& Yancey, G. (2003). Bowling alone but serving together: The congregational norm of community involvement. In C. Smidt (Ed.), Religion as Social Capital producing the common good (pp. 19-31). Waco, Texas: Baylor University Press.

Casseus Jules. (1994). Haiti: What kind of church... what kind of freedom? Cap-Haitien, Limbe: Seminaire Theologique Baptiste d'haiti.

Claret, L. (2004, December 22). Interview by Y Ménard-Saint Clair [Personal Interview]. Causes of conversion from Catholicism to Protestantism in Haiti and the role of vodou after conversion.

Coleman John A. S.J. (2003). Religious social capital: Its Nature, Social Location, and Limits. In C. Smidt. (Eds.) Religion as social capital producing the common good (pp. 33-47). Waco, Texas: Baylor University Press. 
Desmangles, Leslie Gérald. (1992). The faces of the gods: Vodou and Roman Catholicism in Haiti. Chapel Hill, NC: The University of North Carolina Press.

Déita. (1993). La legende des Loa du Vodou Haitien.Port-Au-Prince, Haiti: Bibliotheque National d'Haiti.

Evans-Pritchard, Edward Evan. (1965). Theories of Primitive Religion. Oxford: Clarendon Press.

Evans-Pritchard, Edward Evan, Eliade Mircea. (1999). Religious conversion: Contemporary practices and controversies. In I. Lamb Christopher, Bryant Darrol M. (Eds.), New York, NY: Cassell.

Flinn, F. (1999). Conversion: up from evangelicalism or the Pentecostal and charismatic experience. In C. Lamb \& D. Bryant (Eds.), religious conversion contemporary practices and controversies (pp. 51-74). New York, NY: Cassell.

Fontus Fritz. (2001). Les Eglises Protestantes en Haiti: Communication et Inculturation. Paris, France: Harmattan.

Freedman Samuel, G. (2010, 02 19). Myth obscure Vodou, source of comfort in Haiti. New York Times. Retrieved from http://www.nytimes.com/2010/02/20/world/americas/20religion.html?_r=0

Geertz Clifford. (1973). The Interpretation of Cultures: Selected Essays. New Nork, NY: Basic Books.

Hurbon, Laennec (1995). Voodoo search for the spirit. New York, NY: Harry N. Abrams, Inc.

Hurbon Laennec. (2001). Current Evolution between Religion and Politics in Haiti. In I. Taylor Patrick (Ed.), Nation Dance: Religion, identity, and cultural differences in the Caribbean (pp. 118-125). Bloomington, Indianapolis: Indiana University Press.

Jean Marie, R. (2004, April 20). Interview by Y. Ménard-Saint Clair [Personal Interview]. Causes of conversion from Catholicism to Protestantism in Haiti and the role of Vodou after conversion.

Kim Sebastian, C. H. (2003). In search of identity: Debates on religious conversion in India. New Delhi, India: Oxford University press.

Lain Eugene, C. (1998). Church growth and evangelism in Haiti: needs, problems, and methods. (Master's thesis, Asbury Theological Seminary), Available from Asbury theological elibrary. 
Laguerre, M. (1989). Voodoo and politics in Haiti. New York, NY: St Martin Press.

Louis Andre, J. (1997). Catholicism, Protestantism and a Model of Effective Ministry in the Context of Voodoo in Haiti. (Unpublished Master's Thesis, Fuller Theological Seminary).

Louis Bertin, M. J. (2010).Haitian Protestant views of Vodou and the importance of karacte within a transnational social field. Manuscript submitted for publication, African studies, University of Tennessee, Knoxville, US. , Available from http://trace.edu.

Louis IV. (1687, May 6). The Code Noir (the black code). Retrieved from http://chnm.gmu.edu/revolution/d/335.

Massino Leone. (2004). Religious Conversion and Identity. New York, NY: Routledge.

McBride Lebron, J. (2000). Disappointment with the church. New York, NY: Writers Press Club.

McAlister Elizabeth, A. (2002). Rara! : Vodou, Power, and Performance in Haiti and its Diaspora Berkeley, California: University of California Press.

Mendoza Marcela. (2003). Converted Christians, Shamans and the House of God: The Reasons for Conversion Given by Western Toba of the Argentino Chaco. In I. Buckster Andrew \& D. Glazier Stephen (Eds.), The Anthropology of Religious Conversion (pp. 199-210). Lanham, Maryland: Rowman \& Littlefield publishers, Inc.

Merrill John. (1996). Vodou and political reforms in Haiti: Some lessons for international community. Fletcher F. World Aff. 20, 31.

Metraux Alfred. (1995). Le Vaudou Haitien. Paris, France: Gallimard.

Min Pyong, G. (2002). Literature review with a focus on major theme. In G. Min Pyong \& J. Kim Ha (Eds.), Religion in Asian America building faith communities (pp. 15-36). Lanham, MD: Rowman \& Littlefield Publishers, Inc.

Mooney Margarita, A. (2009). Faith makes us live: Surviving and thriving in the Haitian Diaspora. Los Angeles, California: University of California Press.

Nerestant Micial M. (1994). Religions et politique en Haiti (1804-1990). (2 ed.). Paris, France: KARTHALA.

Nerestant Micial, M. (1999). L'église d'Haïti a l'aube du troisième millénaire essai de théologie pratique et de sociologie religieuse. Paris, France: KARTHALA.

Norris Rebecca S. (2003). Converting to What? Embodied Culture and the Adoption of New Beliefs. In I. Huckster Andrew \& D. Glazier Stephen (Eds.), the Anthropology of 
Religious Conversion (pp. 171-182). Lanham, Maryland: Rowan \& Littlefield publishers, Inc.

Eddie Geoffrey, A. (1997).Old Wine in New Bottles? Kartabhaja (Vaishnava) Converts to Evangelical Christianity in Bengal. In I. Oddie Geoffrey (Ed.), Religious Conversion movements in south Asia; Continuities and change, 1800-1900 Richmon, Surrey: Curzon Press.

Pals, D. (1996). Seven Theories of Religion. New York, NY: Oxford University Press, 1996.

Phillipe, F. (2004, December 22). Interview by Y Menard-Saint Clair [Personal Interview]. Causes of conversion from Catholicism to Protestantism in Haiti and the role of Vodou after conversion.

Pierre Louis, J. (2011, July 24). Azor's funeral. Retrieved from http://www.haitixchange.com (1998). R. Premdas Ralph (Ed.), Ethnicity, and Culture in the Caribbean St. Augustine, Trinidad and Tobago: University of the West Indies, School of Continuing Studies.

Rambo Lewis R,.(2003). Anthropology and the Study of Conversion. In I. Buckster Andrew \& D. Glazier Stephen (Eds.), The Anthropology of Religious Conversion (pp. 211-222). Lanham, Maryland: Rowman \& Littlefield publishers, Inc.

Rambo Lewis, R. (1993).Understanding Religious Conversion. New Haven, Conneticut: Yale University.

Recensement Général de la Population et de l'Habitat RGPH (1971). IHSI, Port-auPrince, Haiti

Recensement Général de la Population et de l'Habitat RGPH (1982). IHSI, Port-auPrince, Haiti

Recensement Général de la Population et de l'Habitat RGPH (2003). IHSI, Port-auPrince, Haiti

Rey Terry. (1999). Our lady of class struggle: The cult of the Virgin Mary in Haiti. Trenton: Africa World Press.

Rice Michele Claire. (2001). The Ellison Model Building Communities through Mentoring (pp. 1-26). North Miami, Florida: ICB Productions Inc.

Richardson T, J. (1978). Conversion Careers: In and Out of the New Religions. (6 ed., Vol. 20). Beverly Hills, Calif.: Sage Publications.

Richman Karen, E. (2008). A More Powerful Sorcerer: Conversion, Capital, and Haitian Transnational Migration. NWIG: New West Indian guide, 82(1-2), 3-45. 
Saliba John A,. (2004). Psychology and the New Religious Movements. In I. James Lewis R. (Ed.), The Oxford Handbook of New Religious Movements (pp. 317-333). New York, NY: Oxford University Press, Inc.

San Buenaventura, S. (2002). Filipino religion at home or abroad: Historical roots and immigrant transformations. In G. Min Pyong \& J. Kim Ha (Eds.), Religion in Asian America building faith communities (pp. 185-214). Lanham, MD: Rowman \& Littlefield Publishers, Inc.

Smucker Glenn R. (1984). The Social Character of Religion in Rural Haiti. In Haiti today and Tomorrow: In Interdisciplinary Study. In I. Foster Charles F and Albert Valdman (Eds.), (pp. 35-56). Landham, MD: University Press of America.

Southeastern National Tuberculosis Center. (2009). Haiti cultural competency and tuberculosis control: A practical guide for health professionals working with foreign-born clients. Retrieved from PDF: http://sntc.medicine.ufl.edu/Files/Products/Country Guide\%

Tselos, S. (2000). Dressing the divine horsemen: Dress as spirit identification in Haitian Vodou. In L. Arthur (Ed.), Undressing Religion (pp. 45-63). New York, NY: Berg of Oxford International.

Walton, D. (2006). Medicine and Social Justice: A Summer in Haiti. Retrieved from photos.pih.org/inforesources/essays/Medicine-Justice-Haiti.html

(2010). Background on Haiti \& Haitian Culture. Silver Spring, MD: Cook Ross Inc. Retrieved from http://www.cookross.com/contact us.asp

(2006). I. Bellegarde-Smith Patrick \& I. Michel Claudine (Eds.), Haitian Vodou: Spirit, Myth, and Reality Bloomington, Indianna: Indiana University Press.

(2006). I. Bellegarde-Smith Patrick \& I. Michel Claudine (Eds.), Vodou in Haitian life: Invisible powers New York, NY: Palgrave Macmillan.

(1999). I. Lamb Christopher \& M. Bryant Darrol (Eds.), Religious Conversion: Contemporary practices and controversies New York, NY: Cassell.

(1998). R. Bowen John (Ed.), Religion in Culture and Society Boston, MS: Allyn and bacon.

(1995). J. Consentino Donald (Ed.), Sacred Arts of Haitian Vodou Los Angeles, California: UCLA Fowler Museum of Cultural History.

(1999). R. Premdas (Ed.), Identity, ethnicity and culture in the CaribbeanTrinidad and Tobago: University of the West Indies. 
(1978). T. Richardson James (Ed.), Conversion Careers In and Out of the New Religions Beverly Hills, California: Sage publications, Inc. 


\section{APPENDICES}

\section{Appendix A}

Agwe- Spirit of the sea, imaged as admiral or ship's captain of boat Imamou, who conduct the dead to their ancestral home.

Ayida Wèdo- Female divinity, wife of Danbala

Bizango- Secret societies

Bondye-God

Bòkò-expert in supernatural matters, who works with both hands-for creation and destruction

Bosal- Wild untamed

Danbala- Rada serpent deity associated with water, the rainbow, cool, and wisdom; often known as danbala Wedo

Dantò- Family of divinities on the petwo side, including Ezili and Ti Jean

Ezili Dantò-Petwo mother warrior spirit

Ezili Freda-Feminin Rada spirit of love; often addressed as Metres 'Mistress'

Gran Mèt- God (Grand Master)

Lakou- family compound or Household

Lougarou- Werewolf, evildoer

Lwa- Spirit deity; lwa ginen, the spirits of Africa, Rada Lwa rasin (root spirits or lwa ginen); lwa travay, (working divinity). Each temple is under the patronage of one or more lwa travay

Maji- magic 
Makout- straw bag; accroutement of Zaka; also short for Tonton Makout, Papa Doc's private militia.

Maladi- sickness

Mistè- 'mystery' divine forces

Nanchon- (Spirit) nations-Within Haitian Vodou

Nanm- Soul, conscience; substance, energy

Marasa-sacred twins

Ogou- Family of warrior spirits known for strong sense of justice. (Sen Jak Maje) Saint James Major

Ounfò- Vodou temple

Ougan- Vodou Priests

Peristil-Vodou temple, Perystile

Petwo- (Petro)-Pantheon of 'hot' spirits, derived from Kongo and slavery experience, magical body of spirits invoked by cracking whips, lighting gunfire, pouring kleren

Poto Mitan- Sacred center pole of the Perystile, through which lwa are said to arrive

Rada-Pantheon \& rites of 'cool' spirits from Ginen (West Africa)

Rara- Masquerade bands associated with Vodou societies that play from January to Easter

Sanpwèl- Secret society

Sump- A simple charm

Tonton Makout- Uncle snap sac; boogeyman, armed guard from Duvalier's private police

Sen- Saint, divinity (Lwa, mistè, zanj) 
Appendix B

\section{$\underline{\text { Religious Congregations from Europe and Canada in Haiti }}$}

1. Soeur de St Joseph de St Vallier

2. Les filles de la Sagesse

3. Soeurs de St Paul de Chartres

4. Soeurs de la Charité de Ste Thérèse

5. Filles de Marie

6. Soeurs de St Joseph de Cluny

7. Soeurs de St François d'Assise

8. La Sainte Union des Sacré-Coeurs

9. Les filles de Jésus

Soeurs Marianites de Sainte Croix

10. Les filles de Marie Auxiliatrice (Salésiennes)

11. Soeurs Dominicaines

12. Missionaires Laïques de Fribourg

13. Frères de l'Instruction Chrétienne (F.I.C.)

14. Les Frères du Sacré-Coeur

15. Les Frères Maristes

16. Pères Dominicains

17. Les Pères du St Esprit

18. Les Rédemptoristes

19. Missionaires Oblats de Marie Immaculée

20. Les Pères de Sainte Croix

21. Les clercs de St Viateur

22. Les Pères missionnaires de Scheut

23. Les Salésiens

24. Missionaires St Charles

25. Les soeurs de la Charité de Saint Hyacinthe

26. Soeurs du Sauveur

27. Les Soeurs de Sainte Anne

28. Missionnaire de l'Immaculée Conception

29. Notre Dame du Bon Conseil

30. Soeurs Missionnaires du Christ-Roi

31. Soeurs Dominicaines, Missionnaires Adoratrices

32. Soeurs de la Charité d' Ottawa

33. Soeurs du Bon Pasteur

34. Oblates Missionnaires de Marie Immaculée

35. Institut Séculier Voluntas Dei

Les petites Soeurs de Sainte Thérèse de l'Enfant Jésus 
Les petits Frères de Sainte Thérèse de l'Enfant Jésus

36. Compagnes de Jésus

37. Filles de Marie Reine Immaculée

38. Petits Frères de l'Incarnation

Les petites Soeurs de Jésus Hostie et du Coeur Immaculée de Marie

39. Missionnaire de la Charité

Source: L'Eglise d'Haiti a l'aube du Troisieme Millenaire. 
Appendix C

Churches and Missions in Haïti by Departments

PORT-AU-PRINCE: Centre Ville, Delmas, Carrefour, Martissant, Carrefourfeuilles,Cazeau, Cite Millitaire, St. Martin, Turgeau Cite Soleil, Petionville, Croix des Bouquets, Grand-Goave, Petit-Goave, Gressier, Leogane

\section{$\underline{\text { Port-Au-Prince (centre Ville) }}$}

1. Premiere Église baptiste de Port-Au-Prince

2. Assemblée Foi et Salut, Actes 16,31

3. Association des églises Missionnaires

4. Églises Centre Évangélique Jean 3.16

5. Croisade Estudiantine et Professionnelle: Campus pour Christ

6. Jour mondial de prière

7. Évangélisation Bible Mission

8. Full Gospel Church

9. Église Béthel, Assemblée Chrétienne Gospel tract society Inc.

10. Alliance Évangélique d'Haïti

11. Église évangélique international, soldat de la Croix du Christ

12. Église de la Victoire 2 Rois 6.16

13. Église de Dieu, l'Unité des Frères Évangéliques de la Sainte Cité

14. Église de Dieu

15. Église gnostique apostolique universelle

16. Église Béthel Défenseur de la foi chrétienne

17. Église chrétienne des Rachtés d'Haïti

18. Temple Mahalaléel

19. Église baptiste évangélique de Mont Joli

20. L'Église Union baptiste

21. Église évangélique baptiste de la Vigne

22. Église apostolique de Jésus-Christ

23. Église du Nazaréen libre

24. Église du Tabernacle

25. Église Universelle de Dieu

26. Église évangélique internationale de Callebasse

27. Église évangélique Rocher du siècle

28. Église de Dieu Pentecôtiste libre à Haïti

29. Église de Dieu Mont Sinaï 
30. Église de Dieu de la prophétie

31. Église de Dieu des frères unis non pentecôtistes

32. Église de Dieu de la nouvelles Jérusalem

33. Église de Dieu en Christ de la nouvelle Alliance

34. Église de Dieu de la Dernière Heure

35. Congrégation fraternelle Notre Dame

36. Église de Dieu primitive

37. Église évangélique assemblée chrétienne d'Haïti

38. Église Assemblée de l'Évangile du corps du Christ

39. Églises Chrétienne de la Rhéma

40. Église du Christ de Port-Au-Prince

41. Église de Jésus Christ Full Gospel

42. Église pentecostale de la Sainteté

43. Église Tabernacle évangélique du people de Dieu

44. Église Ministère "Têt Kolé Nan Kris"

45. Église de la communauté évangélique d'Haïti

46. Église dévouée pour Christ

47. Église Évangélique Béthel, Assemblée Chrétienne, ci-devant Église Béthel

48. Assemblée chrétienne

49. Église évangélique ministère de la Croix

50. Association des Églises baptistes du Bon Berger

51. Église Baptiste de la fraternité

52. Église évangélique ministère de la Croix

53. Église de Dieu Eben-Ezer

54. Église de Dieu, Tabernacle de Jésus Christ Eben-Ezer

55. Église Évangéliste Anglicane Haïtienne

56. Église de Dieu Communion chrétienne de Troutier

57. Église chrétienne Émmanuel

58. Église de l'unification

59. Église Armée du Salut

60. Église baptiste des Cités

61. Église Apostolic Évangélistic Ass. Inc.

62. Église du Dieu vivant

63. Église centre de la foi

64. Église de la Christianisation d'Haïti

65. Église évangélique de la vérité pour les nations

66. Église chrétienne Pentecôtiste

67. Église sainte universelle

68. Église, Salut pour tous

69. Église baptiste du calvaire

70. Église baptiste de la grâce

71. Église baptiste indépendante

72. Église Béthésda

73. Église baptiste Béraca

74. Eglise baptiste de Waney 
75. Église de l'Alliance Chrétienne Indépendante

76. Église du christianisme du 20ème siècle

77. Église évangélique indigène d'Haïti

78. Église évangélique Salem

79. Église missionnaire de Dieu

80. Église Pélerin de la Bible

81. Églises assemblée des Premiers nés de Jésus Christ

82. Église de Jésus Christ

83. Église Évangélique Christ du Peuple de Dieu de Carrefour

84. Église Salut et délivrance indépendante d'Haïti

85. Église de Dieu Sainte cité

86. Église de Dieu Philadelphie

87. Église de Dieu, fondation-association chrétienne

88. Église chrétienne indépendante

89. Église Tabernacle du Dieu de la Grâce

90. Église chapelle évangélique Lumière

91. L'Église, assemblée de Dieu

92. Église baptiste Unie

93. Première Église protéstante de Pétionville

94. Haït Christian Orphanage

95. Assemblée des Ouvriers du Christ d'Haïti

96. Le Petit troupeau

97. Union Fraternité Chrétienne de Calebasse

98. Église communion de la manne évangélique d'Haïti

99. Église deliverance

100. Église évangélique assemblée pentecostale

101. La Première Église évangélique Interdénominationnelle

102. Église réorganisée de Jésus-Christ

103. Église-Assemblée de la promesse

104. Église évangélique quadrangulaire

105. Église de Dieu Pentecostale recouvrement pentecôtiste Pnternationale.

106. Première Église de Dieu Indépendante d'Haïti

107. Église Évangélique Béthel Assemblée Chrétienne

108. Église Évangélique Christ Vivant Rocher des Siècles

109. Église Éangélique des Coeurs Unis de Bel-Air Fort Jacques

110. Églises Baptiste Conservatrice

\section{Missions in the west department at Delmas in}

\section{Port-au-Prince}

1. Haïti Mission service

2. Mission Internationale d'outre-Mer

3. Lifeline Cristian Mission

4. Mission Évangélique de la Nouvelle Jérusalem d'Haiti

5. Mission pour Christ 
6. Mission Quizquéya Chapel

7. Mission de la Nouvelle Angleterre et du Monde

8. Mission Extension Évangélique mondiale

9. Mission Évangélique Unie Internationale

10. Mission Christianville formation

11. Mission aux Amériques

12. Mission des églises de Dieu, Actes des Apôtres XII

13. Mission évangélique baptiste Holiness

13. Assemblée de Dieu en Haïti

14. Mahalaléel, Centre de louange à l'Éternel

15. Pécheur d'hommes international

16. Sant krétyien pour dévelopman intégré

17. Croisade évangélique d'Haiti $<<$ Tabernacle de la grâce $>>$

18. Christ's Messengers in Action

19. La maison de Dieu

20. Union baptiste-Assemblée chrétienne

21. Tabernacle évangélique de Béthel

22. Temple évangélique du Golgotha

23. Fédération Protéstante d'Haiti

24. Evangelical bible mission

25. Mission église de Dieu indigène du Christianisme

26. Mission église évangélique la foi apostolique

27. Mission évangélique du Christianisme

28. Mission messager de Dieu du 7ème jour

29. Mission Tabernacle de la foi

30. Mission Émmanuel par la foi

31. Mission église du pélerin d'Haïti

32. Église évangélique troupeau de Jésus

33. La mission évangélique baptiste d'Haïti

34. Mission évangélique baptiste indigène d'Haïti

35. Mission évangélique d'Haïti

36. Mission la foi apostolique

37. Mission église chrétienne de la Rédemption

38. Mission Pencôtiste libre église de Dieu en Christ

39. Mission de Dieu Béthésda d'Haïti

40. Mission chrétienne de Berée d'Haïti

41. Mission nouvelle vie d'Haïti

42. Mission Montagne des Oliviers

43. Société biblique Haïtienne

44. Conseil National Spirituel des Églises d'Haïti (Conafresh)

45. Mission croisade du salut d'Haïti

46. Ministère Shabach international, Famille tabernacle de louange

47. Fondation mission Haïtienne par la foi

48. Mission Béthanie indépendante d'Haïti 
49. Missions des chrétiens évangéliques unifiés

50. Mission évangélique de la dernière heure

51. Mission Tabernacle évangélique saint temple des Oliviers Inc.

52. Macédonia World Association, baptiste mission

53. Mission Église de Jésus-Christ, la foi des apôtres

54. Mission Église de Dieu Pentecôstal par la foi

55. Mission (Église) évangélique pour la foi

56. Mission évangélique indigène

57. Conseil National des missions évangéliques (Conamise)

58. Haiti Mission Inc.

\section{Churches and mission groups in the West department in the areas around Port-Au-Prince}

MARTISSANT

1. Église Gospel Assembly

2. Église Théophile au Christ d'Haïti

CARREFOUR FEUILLES

1. Église de Dieu de la Grâce

2. Église de Dieu Indépendante

3. Assemblée des Églises Chrétiennes

\section{CAZEAU}

1. Concile des Églises Évangéliques d'Haïti (C.E.E.H.)

2. Église Évangélique de la Bible

3. Église de Dieu maison de refuge

4. Église de Dieu des Premiers Chrétiens

\section{CITÉ MILLITAIRE}

1. Église Centre Évangélique des frères Unis du Christ par la foi

2. Croisade d'Évangélique Mondiale

3. Église de l'Harmonie

ST MARTIN/CITÉ ST MARTIN

1. 2ème Église Baptiste de Port-Au-Prince

2. Église de Dieu Maranatha

3. Mission Messager de Dieu au 7ème jour

BOLOSSE (derrière le fort Dimanche)

1. Union Évangélique Baptiste d'Haïti

FORT NATIONALE

1. Église Armée du Christ 
2. Église Christ Sanctifié

BON REPOS

1. Église de la Nouvelle Alliance

CARREFOUR MARTIN

1. Église de Dieu au Christ Ressuscité

TURGEAU

1. Église de Dieu des Frères Unis non Pentecôtistes

ROUTE DE L"AÉROPORT

1. Église Assemblée des Premiers Nés d'Haïti

SANS FIL

1. Église de Dieu d'Haïti

CITÉ SOLEIL

1. Église de Jésus-Christ Matthieu 16-18

PÉTIONVILLE/KENSCOFF (Missions)

1. Mission Communion de la foi Internationle

2. La mission Communion de l'Église Lumière

3. Mision Évangélique temple de la Bible

4. Mission Coeur de Jésus de la Pentecôte d'Haïti

5. Mission de l'Église Internationale du Christ d'Haïti de Kenscoff

6. Mission Caraibéenne Maranatha

CROIX DES BOUQUETS (Missions)

1. Mission Assemblée de la grâce

2. Mission de l'Église de Dieu Assemblée de la Montagne d'Haïti

3. Mission Église de Dieu information Dernier Message

4. La mission Évangélique de l'unité d'Haïti

5. Mission Sainte Thérèse de l'Enfant Jésus

6. Association chrétienne: les témoins de Jéhova

$\underline{\text { Churches and Missions in Other regions in the West }}$ (Port-Au-Prince)

1. Église Assemblée de Dieu Indépendante

2. La Mission Apostolique d'Haïti

3. Mission Évangélique Chrétienne d'Haïti

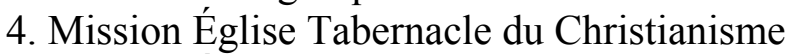

5. Mission Évangélique Baptiste Béthésda
Grand-Goâve

Petit Goâve

Gressier

Gressier

Gauthier 


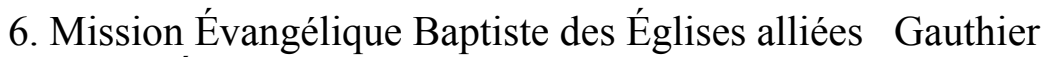

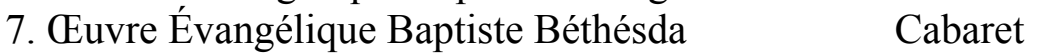

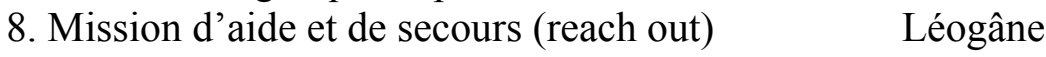

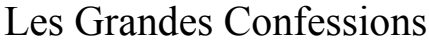

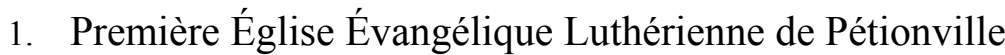

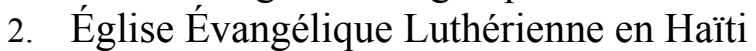

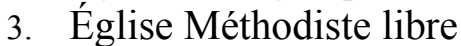

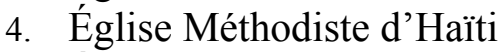

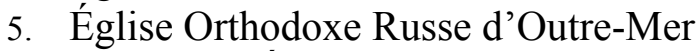

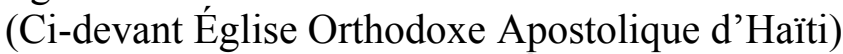

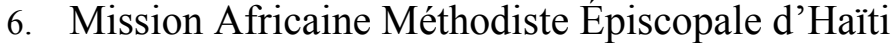

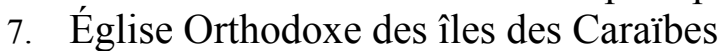

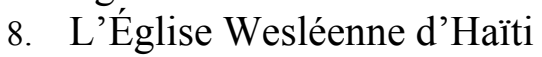

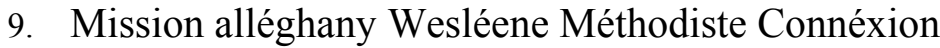

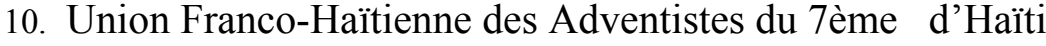

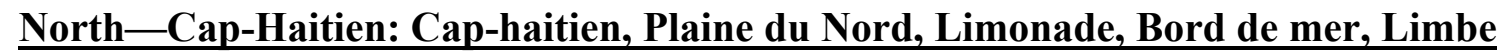

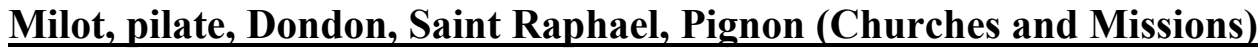

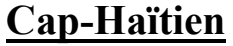

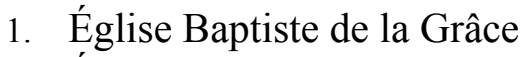

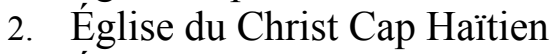

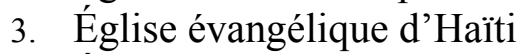

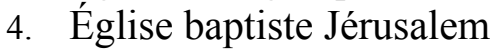

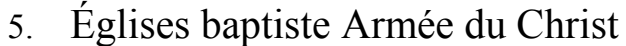

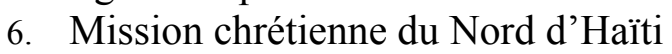

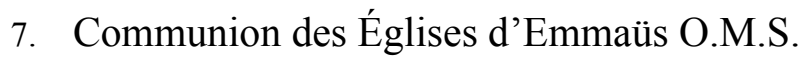

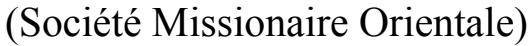

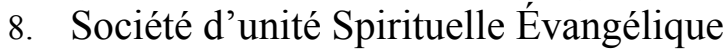

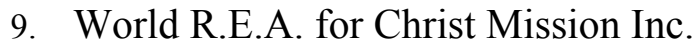

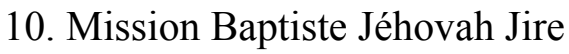

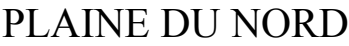

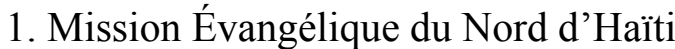

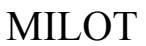

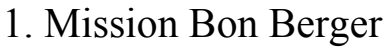

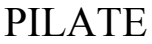

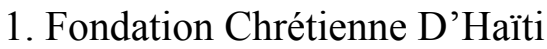

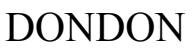

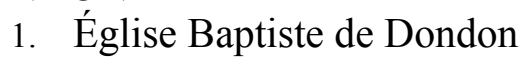




\section{SAINT RAPHAEL}

1. Église Baptiste du Nouveau Téstament

2. Églises Évangélique Haïtienne

PIGNON

1. Église Évangélique Baptiste de Pignon

\section{Churches and Missions by region, department of Artibonite}

Gonaives St. Marc,Marchand Dessalines, Petite Rivière de l'Artibonite, Verrettes, Anse Rouge, Gros Morne

\section{GONAIVES}

1. Église de la Foi Apostolique (Maranatha)

2. Église de Grèce Union Chrétienne des Gonaïves en Haïti

3. Église de la Mission évangélique maranatha

4. Église de la Mission baptiste Maranatha de l'Artibonite

5. Église chrétienne disciples du Christ

6. Églises évangéliques Eben-Ezer

7. Alliance missionnaire Haïtienne des Gonaïves

8. La Croix New-Testament Mission Haïti

9. Missions des églises baptites conservatrices indigènes d'Haïti

10. Mission Baptiste indépendante d'Haïti

11. Mission Église chrétienne

12. Mission baptiste Béthanie à l'intérieur

\section{$\underline{\text { SAINT-MARC }}$}

1. Église méssianique de Dieu maison de refuge

2. Église de Dieu Mont Mébo indépendante d'Haïti

3. Église pentecôtiste Maranatha

4. Église de Dieu melchisédech

5. Sharing Christ's love in Haïti

6. Mission Montagne

7. Organisation d'assistance évangélique d'Haïti (Projet Help Eglise de Borel)

Marchand Déssalines

1. Église de Dieu à l'intérieur d'Haïti

2. Église de Dieu Mont des Oliviers

PETITE RIVIERE DE L'ARTIBONITE

1. Mission Montagne de l'Éternel 


\section{VERRETTES}

1. Églises de la Nouvelle Jérusalem

2. Mission Méthodiste Péniel d'Haïti

\section{ANSE ROUGE}

1. Assemblée indépendante des Églises Baptistes d'Anse Rouge

GROS MORNE

1. Mission Baptiste Pénie

South and Grand Anse Department Cayes, Miragaône, Petite Rivière De Nippes,

\section{Fond des Nègres La Colline, Jérémie}

\section{CAYES}

1. Églises Luthérienne Jérusalem d'Haïti

2. Église Évangélique Luthérienne d'Haïti

3. Mission Évangélique Sud d' Haïti (M.E.B.H)

4. Mission Évangélique Béthanie d'Haiti

5. Mission Béthésda des Cayes

\section{MIRAGOANE}

1. Église Chrétienne Inc.

2. Église Présbytérienne d'Haïti

3. Communion Mennonite d'Haït

4. Mission Union Chrétienne Inc.

PETITE RIVIERE DE NIPPES

1. Église Mission Pentecôtiste

FONDS DES NEGRES

1. Église Présbytérienne d'Haïti

\section{LA COLLINE}

1. Mission Fils de Lumière d'Haïti

JEREMIE

1. Mission par la foi

North West Department Port-de-Paix, Bombardopolis, Jean Rabel, Saint Louis

Port-De-Paix

1. Église baptiste Béthanie 
2. Église de Dieu de la pentecôte de Port-De-Paix

3. Nouvelle Mission de l'église baptiste Haïtienne

Bombardopolis

1. Église baptiste indépendante de Bombardopolis

2. Églises évangéliques baptistes associées

3. Association des Eglises évangéliques d'Haïti et Bonne-Nouvelle

Jean Rabel

1. Églises évangéliques indépendantes Unies d'Haïti

2. Églises de Dieu indépendante d'Haïti

\section{South East Department Jacmel, Cayes-Jacmel,Belle-Anse}

Jacmel

1. Église baptiste stricte de Jacmel

2. Église évangélique baptiste Eben-Ezer

3. Église baptiste révélation évangélique

4. Église chrétienne évangélique (Christ Gospel Church)

5. Baptiste Med-Missions

Cayes- Jacmel

2. L'Église évangélique baptiste des orangers

Belle-Anse

1. Mission de l'église pentecôtiste Haïtienne

Hinche

Plateau Central Department Hinche, Cerca Cavajal

1. Église baptiste de Hinche

Cerca Cavajal

2. Mission Béthel de Cerca Cavajal 


\section{Appendix D}

\section{Protestant Churches and Missions in Haiti by Departments}

\begin{tabular}{|l|c|c|c|c|c|c|c|c|c|}
\hline & West & North & Artibonite & South & $\begin{array}{l}\text { North } \\
\text { West }\end{array}$ & $\begin{array}{l}\text { South } \\
\text { East }\end{array}$ & Centre & $\begin{array}{l}\text { North } \\
\text { East }\end{array}$ & Grand'Anse \\
\hline $\begin{array}{l}\text { Churches/ } \\
\text { Missions }\end{array}$ & 224 & 17 & 26 & 1 & 8 & 7 & 2 & 0 & 9 \\
\hline
\end{tabular}

(Serving 9 Departments, 41 Arrondissements, 132 Communes)

\begin{tabular}{|c|c|c|}
\hline DEPARTMENTS $^{55}$ & ARRONDISSEMENTS $^{56}$ & COMMUNES $^{57}$ \\
\hline Artibonite & $\begin{array}{l}\text { Gonaives } \\
\text { Gros-Morne } \\
\text { St.-Marc } \\
\text { Dessalines } \\
\text { Marmelade }\end{array}$ & $\begin{array}{l}\text { Gonaive, Ennery } \\
\text { Gros Morne, Terre Neuve, Anse R. } \\
\text { Saint Marc, Verettes, La chapelle } \\
\text { Dessalines, Petite Riv. De L'Art., } \\
\text { Grande Saline, Desdunes } \\
\text { Marmelade, St. Michel de L'attalaye }\end{array}$ \\
\hline Centre & $\begin{array}{l}\text { Hinche } \\
\text { Mirebalais } \\
\text { Lascahobas } \\
\text { Cerca-La-Source }\end{array}$ & $\begin{array}{l}\text { Hinche, Maissade, Thomonde, et } \\
\text { Cerca Carvajal } \\
\text { Mirebalais, Saut-d'Eau, Boucan Car. } \\
\text { Lascahobas, Belladere, Savanette } \\
\text { Cerca-La-Source, Thomassique }\end{array}$ \\
\hline Grand'Anse & $\begin{array}{l}\text { Jérémie } \\
\text { Anse d'Hainault } \\
\text { Miragoane } \\
\text { Anse-a-Veau } \\
\text { Corail }\end{array}$ & $\begin{array}{l}\text { Jérémie, Abricots, Bonbon, Moron, } \\
\text { Chambellan } \\
\text { Anse d'Hainault, Dame Marie, Les } \\
\text { Irois } \\
\text { Miragoane, Petite Riv. De Nippes, } \\
\text { Anse-a-Veau, Baraderes, L'Azile, } \\
\text { Petit-Trou de Nippes } \\
\text { Corail, Roseaux, Pestel, Beaumont }\end{array}$ \\
\hline Nord & $\begin{array}{l}\text { Cap-Haïtien } \\
\\
\text { Acul du Nord } \\
\text { Grande Riviere du Nord } \\
\text { St. Raphael } \\
\text { Plaisance } \\
\text { Limbé } \\
\text { Borgne }\end{array}$ & $\begin{array}{l}\text { Cap-Haïtien, Limonade, Quartier } \\
\text { Morin } \\
\text { Acul du Nord, Plaine du Nord, milot } \\
\text { Grande Riviere du Nord, Bahon } \\
\text { St. Raphael, Dondon, Ranquitte, la } \\
\text { Victoire, Pignon } \\
\text { Plaisance, Pilate } \\
\text { Limbé, Bas-Limbé } \\
\text { Borgne, Port-Margot }\end{array}$ \\
\hline Nord-Est & $\begin{array}{l}\text { Fort-Liberté } \\
\text { Trou-du-Nord } \\
\text { Vallieres } \\
\end{array}$ & $\begin{array}{l}\text { Fort-Liberté, Ferrier, les Perches } \\
\text { Trou-du-Nord, Caracol, St. Suzanne, } \\
\text { Terrier Rouge } \\
\text { Vallieres, Carice, Mombin-Crochu }\end{array}$ \\
\hline
\end{tabular}

${ }_{55}^{55}$ Departments

${ }^{56}$ Districts

${ }^{57}$ Municipalities 


\begin{tabular}{|c|c|c|}
\hline & 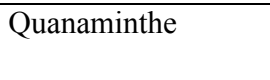 & 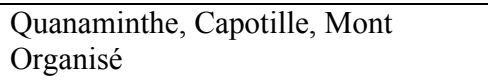 \\
\hline 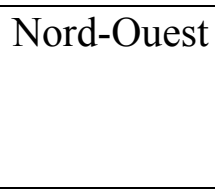 & 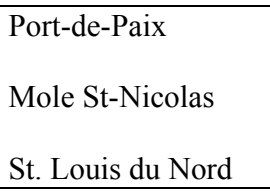 & 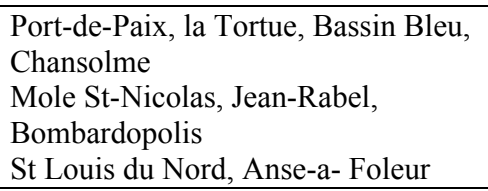 \\
\hline 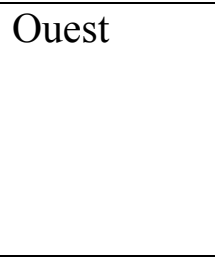 & 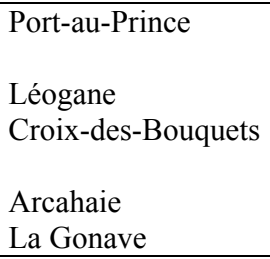 & 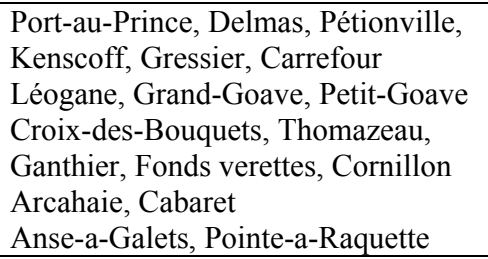 \\
\hline 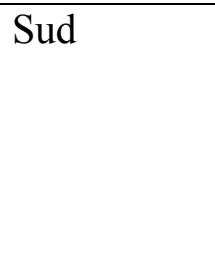 & 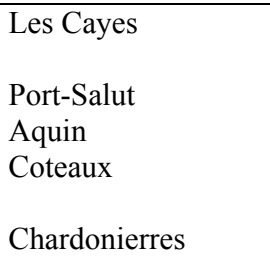 & 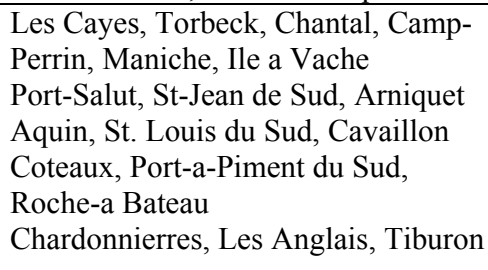 \\
\hline 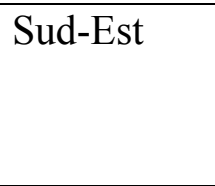 & 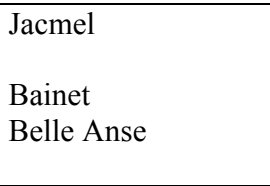 & 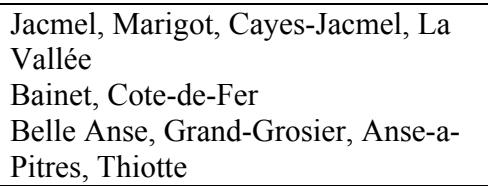 \\
\hline
\end{tabular}

